\title{
EL RETORNO DEL PARNASO
}

\author{
Sed me Parnasi deserta per ardua dulcis \\ raptat amor. Juvat ire jugis, qua nulla priorum \\ Castaliam molli devertitur orbita clivo \\ VIRGILIO, Georgicae III, 291-3.
}

El Viaje del Parnaso (1614) ha marcado hasta fechas muy recientes la última frontera virgen de la crítica cervantina. Desdeñado a título de simple catálogo de elogios poéticos o inmerso en el problema artificial del "Cervantes como poeta", ha estado ahí en espera de una primera generación de críticos modernos dispuestos a leerlo a partir de sus propios supuestos y comprometidos a dar razón de los complejos discursos que en él se entrecruzan.

La tarea es larga y compleja, porque tenemos que habérnoslas con un testimonio vivo de la absoluta madurez de Cervantes y una suma reflexiva de toda su experiencia poética. El Viaje del Parnaso, que quiere decir lo mismo que el viaje a la literatura, nos transmite con un cierto temblor de últimas palabras su definitivo enjuiciamiento de la poesía y de la propia vida consumida en servicio de la misma. Su instinto infalible le previene contra el patetismo del trance y, sin llegar a anularlo del todo, lo diluye con la elegancia de siempre en un denso entramado de paradojas. El poema es un amplio espacio lúdico donde la calculada pugna de ambiguas luces e irónicas sombras se muestra capaz de conseguir, una vez más, el habitual milagro cervantino de una plenitud de comunicación con su lector en las últimas fronteras del lenguaje.

Disponemos hoy, como fruto de la tarea estudiosa, de un panorama bastante completo de sus relaciones genéricas no ya con aquel quidam perusino que se llamó Cesare Caporali (1531-1601)

${ }^{1}$ Conforme a la escasa entidad literaria del autor, la bibliografía italiana 
sino con toda una tradición satírica de visitas o viajes al Parnaso que, en derivación de Dante, Petrarca y Boccaccio, fue además cultivada en el Cinquecento italiano por Filippo Oriolo di Bassano, Pietro Aretino y, ya muy al filo cronológico, Gian Vincenzo Imperiale y Traiano Boccalini ${ }^{2}$. Sabemos asimismo de la larga historia española de los elogios poéticos, de los Olimpos burlescos y de la sátira contra la proliferación de malos poetas y pretenciosos aficionados, temas muy presentes en el ámbito español de los primeros años del siglo XVII ${ }^{3}$.

sobre Caporali es bastante parca. Se reduce virtualmente al estudio bibliográfico de R. A. Gallenga Stuart, Cesare Caporali, Donnini, Perugia, 1903, y su larga y bastante adversa reseña por ABD-EL-KADER SALZA en Giornale Storico della Letteratura Italiana, 46 (1905), 182-199. Sus Viaggio di Parnaso y Avvisi di Parnaso aparecieron en el volumen de sus Rime piacevole, publicado en Parma en 1582. Es muy probable que la memoria de Cervantes fuese al menos refrescada tras la aparición de sus Opere poetiche en Venecia, 1608, como cree FraNcisco Rodrícuez Marín en su ed. del Viaje del Parnaso, Madrid, 1935, p. xv. Aunque Caporali se movió también en el círculo cortesano de los Acquaviva no hay ningún indicio de que Cervantes llegara a conocerlo en persona.

${ }^{2}$ Los hitos bibliográficos son aquí BENEDETTO CROcE, con su estudio de Caporali y la tradición italiana de estos viajes al Parnaso y catálogos poéticos, en "Due illustrazioni al Viaje del Parnaso del Cervantes", en Saggi sulla letteratura italiana del seicento, Laterza, Bari, 1911, pp. 125-159, y antes en Homenaje a Menéndez-Pelayo, Madrid, 1899, t. 1, pp. 161-193. Según Croce, Cervantes tomó la idea de la guerra de los poetas más bien de los Avvisi di Parnaso del mismo Caporali, que no de su reconocido Viaggio (p. 130). Rodríguez Marín da por descontada en su edición (p. xiii) la influencia de la primera centuria de Ragguagli di Parnaso (Venecia, 1612) de Traiano Boccalini, pero sin entrar en estudio particular del problema. Es enfocado éste en sentido más cauto por Robert H. Williams, Boccalini in Spain, Banton Publishing, Menasha, 1946. La admite, en cambio, para la Adjunta al Parnaso Gustavo Correa, "La dimensión mitológica del Viaje del Parnaso de Cervantes", $C L, 12$ (1960), 113124. La insignificante imitación de Caporali es también puesta de relieve por F. D. Maurino, "Cervantes, Cortese, Caporali and their "Journeys to Parnassus»", $M L Q 19$ (1958), 43-46. Augusta LóPEZ-BERNASOcchi, "Una nuova versione del viaggio in Parnasso: "Lo stato rustico" de Gian Vincenzo Imperiale", Studii seicenteschi, 23 (1982), 63-90. Pasa revista a los recuerdos o ecos de origen clásico José Toribio MEdina en su edición del Viaje del Parnaso, Santiago de Chile, 1925, t. 1, pp. xxvii-xxviii (multiplicados en la anotación de ediciones posteriores).

${ }^{3}$ Toribio Medina enlaza a Cervantes con la moda de los catálogos poéticos a partir de La Diana enamorada (1564) de GIL Polo (1, XIII), pero la tradición era bastante más antigua y compleja, como estudia DAVID M. GiTLITZ, "Cervantes y la poesía encomiástica", $A I O N-R, 14$ (1972), 191-218. Sobre la sátira y descrédito de los poetas, con testimonios tan valiosos como el de Miguel SÁnchez de Lima en El arte poética en romance castellano (1590), véase 
Todo ello, sin embargo, no es sino la habitual y exquisita destilación literaria que sirve de prehistoria o subsuelo a los más mínimos aspectos de la obra cervantina. Culminación, al fin y al cabo, de ésta, el Viaje del Parnaso se perfila como desarrollo final de un complejo discurso sobre la naturaleza y función de la poesía que ha sellado al autor en sus años de madurez. Sólo que Cervantes no va a legarnos ni un "manifiesto" a la moderna ni un tratado que añadir a la montaña de los que tantos ingenios de su época lanzaron, sobre todo en Italia, desde el cómodo refugio de la trinchera académica. Desinteresado en la teorización per se, el problema de la poesía es para él indistinguible del problema del poeta y de cómo la vive éste no conforme a una determinada teoría, sino desde dentro de su persona y de sus tiempos. Su discurso se halla así llamado desde el primer momento a asumir un marcado cariz ético y a tomar la forma de una compleja sátira literaria nada alejada, en sus aspectos técnicos, de las constantes más visibles de su arte narrativo.

En medio de un ambiente dominado por las especulaciones y secas polémicas internas de los neoaristotélicos, Cervantes ha marchado desde la misma Galatea (1585) tras una eficaz novelización de sus propias ideas acerca de la poesía ${ }^{4}$. Mucho más sabio, se mostrará capaz de iniciar en el Quijote una reflexión sobre el hic et nunc de la poesía y del poeta bajo una luz de ironía burlesca que obviamente amplía y corona el Viaje del Parnaso. Acta de nacimiento de dicho discurso constituyen los ridículos poemas prologales y epilogales que en la Primera parte enmarcan, a modo de elogio y vejamen, las aventuras del flamante paladín manchego y que cabe situar bajo la culpable y loca autoría de la academia de la Argamasilla ${ }^{5}$. Zona de las menos trabajadas por la crítica, fue allí donde Cervantes mostró ya un irónico a la vez que desolado pesimismo acerca del presente y futuro de la poesía españo-

Rodríguez MARín, "La poca estimación en que eran tenidos los poetas" (Viaje del Parnaso, apéndice 8). Para un amplio tema que abarca al mismo Cervantes, Gonzalo Sobejano, "El mal poeta de comedias en la narrativa del siglo XVII", $H R, 41$ (1973), 313-330.

"La Galatea "explicitly makes the power of poetry its central concern", según pone de relieve MARY GAYLORD RANDEL, "The language of limits and the limits of language: The crisis of poetry in La Galatea", $M L N, 97$ (1982), 254-271, esp. 257.

5 Pierre L. Ullman, "The burlesque poems which frame the Quijote", ACerv, 9 (1961-1962), 213-227. Francisco Márquez Villanueva, “"El mundo literario de los académicos de la Argamasilla", $L T, 1$ (1987), 9-43. 
la, que acéfala y prostituida gira, sin ir a ninguna parte, en turbio y autodestructor remolino. Aspecto allí central es también la cautela hacia el fenómeno académico, en cuanto más alta cumbre visible y proyección social de la experiencia poética de la época.

Resumiendo en pocas palabras lo que en sí constituye un complejo escenario de historia y sociología literaria, el discurso académico de Cervantes no puede ser más negativo. Frente al ejemplo de dignidad dado por las academias de Italia, donde la poesía más culta, significada entonces por la tragedia clásica, reina suprema, las academias españolas ${ }^{6}$ consagran por el contrario la comedia nueva y la poesía "romancista", cuyo abanderado es en ambos casos Lope de Vega, máxima estrella siempre de las academias de la corte. Sirven éstas de plazuela a las pendencias de los poetas, que ventilan allí sus celos profesionales sin escrúpulo de armas prohibidas y han hecho del maligno "vejamen"" el género característico de este panorama en tan mala hora "académico" y cuyo espíritu captan para siempre las tareas de la ridícu-

${ }^{6}$ La historia aún no definitiva de las academias españolas (con datos acerca de la participación de Cervantes) es estudiada en los libros de JosÉ Sán. CHEZ, Academias literarias del Siglo de Oro español, Gredos, Madrid, 1961, y WILLARD F. KING, Prosa novelística y academias literarias del siglo XVII, Madrid, 1963. La afinidad de la comedia de Lope con el espíritu académico y la tendencia de tales círculos a acoger el espíritu picaresco son comentadas por esta última en "The academies and seventeenth-century literature", $P M L A, 75$ (1960), $367-376$, esp. 373 y 375 . Como aquí se reconoce también "for better or for worse $[\ldots]$ much of the literary production of the century bears the stamp of the literary academy" (p. 376). Las academias zaragozanas (segundas en importancia, tras las de la corte) son ahora estudiadas por AURORA EGIDO, "Las academias literarias de Zaragoza en el siglo xviI", La literatura en Aragón, Zaragoza, 1984, pp. 103-128. También de la misma, las sustanciosas páginas de "Una introducción a la poesía y a las academias literarias del siglo XVII", Estudios Humanisticos. Filologia, León, 6 (1984), 9-25.

${ }^{7}$ Como recoge W. F. KING, el vejamen académico se origina probablemente del actus gallicus o elogio burlesco que las universidades medievales introdujeron en el ceremonial de la concesión de grados superiores (Prosa novelística, p. 93). Ejemplos de esta costumbre, que contribuyó no poco a complicar la vida en los claustros universitarios de la época, pueden verse en el artículo de Aurora EGIDO, "DDe ludo vitando". Gallos áulicos en la Universidad de Salamanca", El Crotalón. Anuario de Filología Española 1 (1984), 609-648. El espíritu y comicidad del vejamen académico son lúcidamente estudiados por Ma. Soledad Carrasco UrGorti, "Notas sobre el vejamen de academia en la segunda mitad del siglo XvII", $R H M, 31$ (1965), 97-111. Se dispone ahora de un estudio particular del máximo especialista de la época en materia de vejámenes, realizado por KenNeth Brown, Anastasio Pantaleón de Ribera (16001629), Studia Humanitatis-Porrúa, Madrid, 1980. 
la Argamasilla. Con grotesca perversidad sus académicos no dominan otro arte que el de la vejación y el pisoteo de las Buenas Letras. Lo mismo Dante que el legado petrarquista y la forma misma del soneto son allí objeto de un envilecedor manoseo por parte de aquellos poetastros capaces de todo. Verdadero salteador de tumbas, el Paniaguado, por ejemplo, se complacía en tan bajo menester como mostrar al mundo la fealdad del cadáver descompuesto de Dulcinea: "Esta que veis de rostro amondogado". La tarea colectiva de la Argamasilla se propone la vejación de los héroes del Quijote no a título gratuito, sino como parte de otro malvado y más amplio designio que no es sino el asesinato de la gran tradición clasicista como foco del concepto de una poesía culta.

Por desgracia, la deprimente visión cervantina no carecía de fuertes asideros. Aunque conocidas desde mucho antes, las academias cobran mucho auge en Madrid en coincidencia aproximada con los primeros años del siglo xvir. Sólo que cuando las de Italia sublimaban la funcionalidad del mecenazgo en aquella suprema expresión del mutuo respeto entre aristócratas y poetas, los próceres que en Madrid las presidían buscaban poco más que divertirse echando a pelear entre sí a los frecuentadores de las musas. Su ambiente e incidencias sólo contribuían al desprestigio de la poesía y a envenenar la vida diaria de los poetas. Luis Vélez de Guevara y Pedro Soto de Rojas se esperan rodela en mano a la salida de una sesión de la Academia del conde de Saldaña, que fenece así ingloriosamente en los primeros meses de $1612^{8}$. El espíritu argamasillesco, que amenaza cubrir la poesía española, es tanto un peligro mortal para ésta como síntoma aún más profundo de una sociedad desquiciada y acéfala.

Tan menguado juicio acerca de las academias, en el que coincidían también otros ingenios (Cristóbal Suárez de Figueroa, Góngora, Cristóbal de Mesa y hasta el mismo Lope), no desanimó a Cervantes de continuar asistiendo a las de la corte, si bien con

${ }^{8}$ Da noticia del lamentable episodio el mismo LOPE DE VEGA en sus cartas al duque de Sessa. El 2 de marzo de 1612 escribía a éste: "Las academias están furiosas: en la pasada se tiraron los bonetes dos licenciados". Días después añade otros detalles: "Esta última se mordieron poéticamente un licenciado Soto, granadino, y el famoso Luis Vélez; llegó la historia hasta rodelas y aguardar a la puerta; hubo príncipes de una parte y de otra, pero nunca Marte miró tan opuestas a las señoras musas"' (Lope DE VEGA, Cartas, ed. N. Marín, Castalia, Madrid, 1985, pp. 110 y 112). Es probable que sea este el motivo de que irónicamente Cervantes lo declare "el bravo" en su poema (II, 168). 
un grado de participación escaso y, por cuanto se sabe, más como taciturno observador que otra cosa. Las academias madrileñas ardieron como nunca en los últimos, decisivos años de su vida y la génesis del poema que nos ocupa no es probablemente ajena a la academia conocida bajo el doble título de El Parnaso y la Selvaje ${ }^{9}$. Sucedió ésta al escandaloso derrumbamiento de la Academia de Saldaña y continuó funcionando hasta el verano de 1614. Su punto final coincide así con el periplo parnasiano de Cervantes y su retorno a la corte, determinado por el dato ante quem de la canícula del mismo año, en que se fecha la carta de Apolo en la Adjunta al Parnaso ${ }^{10}$. Con toda puntualidad, no deja Cervantes de elogiar en el Viaje a su presidente don Fernando de Silva, hermano del duque de Pastrana:

Este gran caballero, que se inclina a la lección de los poetas buenos, y al sacro monte con su luz camina,

Don Francisco de Silva es, por lo menos; ¿qué será por lo más? ¡Oh edad madura, en verdes años de cordura llenos! ${ }^{11}$.

La mera mención del Parnaso bastaba para sugerir en aquellos años un contexto de academias. El poema de Cervantes halla de esta forma su puesto en una cadena de resonancias (por no decir aquí intertextualidades) académicas fácilmente reconocibles. $\mathrm{Ca}$ si al filo de sus fechas de redacción, Pedro Soto de Rojas (para sus colegas "el Ardiente") había mencionado el mismo artificio de los poetas como soldados defensores de las Letras contra los embates de la ignorancia en su Discurso sobre la poética, escrito en el abrirse la Academia Selvaje ${ }^{12}$. No hay que olvidar que el encua-

${ }^{9}$ Resume sus vicisitudes y la participación de Cervantes en la misma LuIS Astrana Marín, Vida ejemplar y heroïca de Miguel de Cervantes Saavedra, Instituto Editorial Reus, Madrid, 1958, t. 7, pp. 17-19.

${ }^{10}$ Como demuestra Herrero García, el poema se hallaba a medio camino de su redacción en el año 1612 (Viaje del Parnaso 8). Rodríguez Marín, por su parte, observaba la extraña coincidencia supuesta por el detalle de las "cosquillas" que producen las seguidillas en Viaje 1, 27 lo mismo que en boca de la condesa Trifaldi (Quijote II, 38): “¿quién sabe si ambos pasajes no se escribieron en un mismo día?" (p. 173).

11 Miguel de Cervantes, Poesías completas, t. 1: Viaje del Parnaso, ed. V. Gaos, Castalia, Madrid, 1973, cap. II, pp. 217-222. Todas las citas textuales se entienden referidas a esta edición.

${ }^{12}$ Recogido en su Desengaño de amor en rimas, Madrid, 1623. "El Ardien- 
dre paradigmático del Viaje del Parnaso reclamaba la guardarropía académica de la época, con sus engolamientos y extravagancias pedantescas, conforme a la mejor tradición del género en Italia. El mismo Cesare Caporali de la confesada imitación cervantina había sido acogido por la academia de los Filomati de Siena y fue sobre todo recordado bajo el nombre de "lo Stemperato", que adoptara en la Accademia degli Insensati de su Perugia natal. El Viaje del Parnaso constituye un supremo ejemplo de literatura académica y en cuanto tal ni siquiera se priva de amueblar su capítulo final de chuscos "Privilegios, ordenanzas y advertencias que Apolo envía a los poetas españoles"'13.

Claro que, viniendo de quien viene, el Viaje del Parnaso habrá de discurrir por los atajos de lo paródico, la paradoja y el seudoelogio, tan familiares ya para todo cervantista de entonces o de ahora. También los poemas de la Argamasilla serían al fin y al cabo, como agudamente dedujo Marcel Bataillon ${ }^{14}$, obra de una auténtica "academia" bodegonera presidida por Cervantes en Valladolid con la colaboración muy probable de Gabriel Lobo Lasso de la Vega (el académico Entreverado) y la ya más discutible de Pedro de Medina Medinilla. El Viaje del Parnaso supone, en una de sus instancias más inmediatas, un pinchar el globo académico con que Cervantes no se ha divertido menos que cuando daba al través con la apolillada balumba caballeresca. Sorna monumental de las pretenciosas pompas académicas, de los bombos mutuos y de sus mezquinas y más o menos soterradas competencias, el nuevo poema no significa a fin de cuentas sino un complemento y digno punto final del discurso inicialmente argamasillesco.

El Viaje del Parnaso reviste, pues, una perfecta legitimidad en este plano inicial de poema jocoso. Pero, a la vez, no hay para Cervantes tema más propicio a su estro que este de la poesía y cuanto la rodea, tanto por lo solemne como por lo cómico. Igual

te" se compara a sí mismo y a su discurso con la trompeta y el tambor que convocan al "escuadrón de sabios" a la batalla contra la ignorancia (PEDRO soto de Rojas, Obras, ed. A. Gallego Morell, CSIC, Madrid, 1950, pp. 2533). El discurso, por lo demás, no es sino una lección de catecismo neoaristotélico de muy escasos alientos. Según Astrana Marín fue pronunciado el 15 de abril de 1612 (Vida ejemplar.y heroica..., t. 7, p. 18).

${ }^{13}$ Las cartas o comunicaciones de Apolo eran parte usual de las tareas académicas (A. EGIDO, "Una introducción a la poesía y a las academias literarias del siglo XVII", p. 22).

14 "Urganda entre Don Quijote y La picara Justina", en Picaros.y picaresca, Taurus, Madrid, 1969, pp. 53-90. 
que sus lectores, la va a gozar muy de veras con aquella donosísima fantasía de la galera que "toda de versos era fabricada" (I, 245), con ballesteras de glosas, chusma de romances, remos de esdrújulos e via dicendo. Ninguna quiebra ni reserva irónica tampoco en la autenticidad luminosa del crucero mediterráneo, el contacto rejuvenecedor con el mar y hasta el toque mitológico de las sirenas, como una nostalgia garcilasista de los buenos tiempos en que todo aquello podía sonar a vanguardia poética. Cervantes no escribió nunca versos más traspasados de clara y restallante alegría. ¿Qué más podría pedir aquí el puro ideal de un clasicismo académico?:

Hasta el tope la vela iba tendida, hecha de muy delgados pensamientos, de varios lizos por amor tejida.

Soplaban dulces y amorosos vientos, todos en popa, y todos se mostraban al gran viaje solamente atentos.

Las sirenas en torno navegaban, dando empellones al bajel lozano, con cuya ayuda en vuelo le llevaban.

(III, 4-12)

Aunque plenamente logrado, este amable nivel no representa sin embargo más que un ligero barniz inicial del poema. Su mayor interés radica en documentar la diversificación risueñamente superadora del cuadro que hoy se nos antoja tétrico o pre-goyesco de la Academia de la Argamasilla. El discurso cervantino se ha vuelto más luminoso y equilibrado con su avance en profundidad, pese a tantas circunstancias adversas. Han transcurrido desde 1605 unos años cruciales y todo se ha vuelto más sombrío. El relativo optimismo de la corte en Valladolid (1601-1606), que tanto contribuyó al espíritu de la Primera parte del Quijote, no fue más que un fuego de paja, pronto olvidado ante un desfile de sucesos ominosos, como la caída de don Pedro Franqueza y el clan o partido "letrado" de los Ramírez de Prado en (1607-1608)15 o la desvergüenza favoritista, a alturas nunca vistas, en el reparto de hábitos y prebendas. La expulsión de los moriscos en 1609, aquel hecho inmenso que Felipe II no se había atrevido a realizar y después del cual desaparecía toda barrera moral al ejercicio del po-

15 Véase Jean-Marc Pelorson, Les "letrados" juristes castillans sous Philippe III, Université de Poitiers, Le Puy -en-Velay, 1980, p. 451. 
der, ha sido el acontecimiento político más hondamente meditado por Cervantes ${ }^{16}$. Los escándalos en torno a la caída de don Rodrigo Calderón y la muerte de la reina Margarita de Austria en 1611 no harán sino oscurecer aún más este cuadro.

Para la literatura, las cosas no han marchado mejor. El saber y el mérito personal se cotizan menos que nunca bajo el rampante sistema de validos. Monarquía, Iglesia y aristocracia confirman ahora su completo desinterés en las letras y como resultado dos magníficas generaciones de poetas (una de jóvenes y otra de viejos como Cervantes) se encuentran a la intemperie, porque en España sencillamente no hay mecenas, lugar ni reconocimiento para tales hombres. Los poetas han de ganarse la vida en toda suerte de indignos menesteres, que van desde escribir comedia tras comedia hasta el desempeño de ambiguas secretarías al servicio de grandes señores. Las arremetidas contra las letras y sus representantes alcanzan una cota a la altura de los peores momentos bajo Felipe II. Recuérdense las dificultades creadas a Eugenio de Narbona por su Doctrina politica y civil (1604), al P. Juan de Mariana a partir de 1610 y el menos conocido empapelamiento de don Lorenzo Ramírez de Prado ${ }^{17}$. En 1612 es condenado éste a cinco años de destierro y dos mil ducados de multa por haber publicado (París, 1607) una edición inexpurgada de Marcial y por atreverse después a defenderla frente a los ataques de los jesuitas. Don Lorenzo no tenía nada de buen poeta, pero ello no da sino un relieve adicional al hecho de que Cervantes le dedicara, en noble vena estoica, uno de los elogios más extensos de todo el Viaje del Parnaso:

Este que viene es un galán, sujeto de la varia fortuna a los vaivenes, y del mudable tiempo al duro aprieto; un tiempo rico de caducos bienes, y ahora de los firmes e inmudables más rico, a tu mandar firme le tienes; pueden los altos riscos siempre estables

${ }^{16}$ Francisco Márquez Villanueva, "El morisco Ricote o la hispana razón de estado", en Personajes y temas del "Quijote», Taurus, Madrid, 1975, pp. 229-335.

17 Pelorson, op. cit., pp. 347 y 340-341. Véase también Joaquín DE ENTrambasaguas, Una familia de ingenios: los Ramirez de Prado, 2 vols., CSIC, Madrid, 1942. Para el caso de Narbona, JEAN VILAR, Intellectuels et noblesse: le doctor Eugenio de Narbona, Université de Rennes, Rennes, 1968. 
ser tocados del mar, mas no movidos

de sus ondas en cursos variables;

ni menos a la tierra trae rendidos

los altos cedros Bóreas, cuando, airado, quiere humillar los más fortalecidos.

$\mathrm{Y}$ este que vivo ejemplo nos ha dado

desta verdad con tal filosofía,

Don Lorenzo Ramírez es de Prado.

(II, 112-126)

En un terreno más cercano al jardín de las musas las cosas no han ido mucho mejor. Ha continuado, arrolladora, la carrera triunfal de la comedia lopesca, en confirmación del teatro como forma de un mecenazgo de nuevo cuño, que ejercen las multitudes mosqueteras y constituye el factor más decisivo de la sociología literaria de la época. Avanzando por el profético carril argamasillesco, las academias madrileñas se aúnan con el corral en el aplauso de Lope, que ahora impera en las mismas como "Apolo" indiscutible. Su Arte nuevo de hacer comedias, presentado a una de ellas en $1609^{18}$, podía perfilarse para muchos buenos ingenios como una herejía o manifiesto anticlasicista, a la vez que como una intolerable desfachatez personal. Escrito en obediencia a un encargo académico, supone la existencia de cierta mar de fondo en relación con su poesía, pero también, dado el silencio posterior, una victoria definitivamente ganada para la misma. No se siguió al Arte nuevo la batalla campal que Lope aceptaba de antemano, si bien el tema de la licitud de su comedia nueva da la impresión de haber permanecido por mucho tiempo como la gran cuestión de trastienda en las academias españolas.

Al igual que casi todos los poetas, la situación personal de Cervantes no hizo sino empeorar, al compás de la vida del reino, durante estos años. Fue durante los mismos cuando adquirió la fama de viejo atrabiliario que arrastraba por desvanes su mísera vida en casi total y, según aquéllos, muy merecida falta de amigos $^{19}$. Siempre con problemas para reunir los obligados prelimi-

18 Véanse datos del estudio preliminar de J. DE José Prades, Arte nuevo de hacer comedias en este tiempo, ed. C. Guerrieri Crocetti, CSIC, Madrid, 1971.

19 Vale la pena recordar aquí las alusiones en este sentido que contiene La dama boba $(\mathrm{I}, 13)$ de Lope y que reconoció Justo García Soriano, Los dos "don Quijotes", Toledo, 1944, pp. 175-176. Igualmente las de la comedia San Diego de Alcalá identificadas por ThOmas E. CASE, "Lope's 1613 answer to Cervantes", $B C, 32$ (1980), 125-129. Por delante de todos había marchado Avellaneda, con la intención de pintarlo en su Prólogo un viejo odioso "y por 
nares poéticos, el Viaje del Parnaso iba a salir sin más que un soneto de "El autor a su pluma":

Pues véis que no me han dado algún soneto que ilustre deste libro la portada, venid vos, pluma mía mal cortada, y hacedle, aunque carezca de discreto.

Cervantes, como se ve, había mendigado en vano algunos sonetos, y ésta seguramente era la situación cuando llegó, en el último instante, el solitario epigrama latino de don Agustín de Casanate $^{20}$. Con desdén de toda actitud de quejumbre, decide Cervantes no pintar, sino subsumir dicha situación dolorosa en la ridícula figura convencional del poeta pobre, dejando aflorar solamente algún que otro toque intencionado acerca de la miseria que deja atrás en Madrid.

Sobre este lamentable cuadro se había posado un rayo de esperanza cuando a mediados de 1608 el duque de Lerma nombra virrey de Nápoles a su yerno don Pedro Fernández de Castro, VII conde de Lemos (1576-1622) ${ }^{21}$. Dentro de aquel panorama desolador, era éste el único aristócrata verdaderamente adicto a las letras, entendido y capaz de un trato digno con las gentes de pluma. Su nombramiento se ofrecía providencial y la tribu poética se movilizó para marchar con él a la ciudad que entonces cifra-

los años tan mal contentadizo, que todo y todos le enfadan, y por ello está tan falto de amigos'”.

${ }^{20}$ La desaparición del soneto introductorio " $\mathrm{El}$ autor a su pluma" en numerosos ejemplares de la edición princeps es posible que se deba, como observó Rodríguez Marín en su comento, al deseo de Cervantes (sorprendido por la aparición del Quijote de Avellaneda y su maligna acusación de hallarse solo y sin amigos) de no dar en esto una sombra de objetividad a su malicioso émulo. Astrana Marín ha dado después una explicación más sencilla, según la cual Cervantes escribió su propio soneto de elogio en vista de la imposibilidad de obtener otras piezas ad hoc de sus reales o supuestos amigos. Iniciada ya la tirada, recibiría el epigrama de Casanate, por lo cual se apresuró a alterar la impresión del pliego inicial con retirada de su soneto (Vida ejemplar y heroica... , t. 7, pp. 106-109).

${ }_{21}$ Biografiado por Alfonso Pardo Manuel de Villena, Un mecenas espanol del siglo XVII. El conde de Lemos, Madrid, 1912, con capítulo dedicado a los preparativos de su ida a Nápoles y relaciones con Cervantes y otros poetas (pp. 101-114). Véanse también los estudios de Otis H. Green, Vida y obras de Lupercio Leonardo de Argensola, University of.Pennsylvania, Philadelphia, 1927, pp. 87-96, "The Literary Court of the Conde de Lemos at Naples (1610-1616)"', $H R, 1$ (1933), 290-308. 
ba para los españoles la suma de todos los placeres, "la más rica y más viciosa ciudad que había en todo el universo mundo", en palabras del Quijote (I, 51). No fue sólo Cervantes, sino Cristóbal de Mesa, Cristóbal Suárez de Figueroa y hasta don Luis de Góngora quienes se ilusionaron con formar parte del Parnaso poético que en Nápoles iba a reunir aquel nuevo Apolo español. Se comprende que Lemos hubiera de protegerse contra aquel asedio general: "Hallé tan sitiado al conde de ingeniosos, que le juzgué inaccesible" escribe con su filo Suárez de Figueroa ${ }^{22}$. No se siguió, sin embargo, más que una desilusión general, pues los hermanos Argensola, encargados de reclutar el séquito, repartieron a los cuatro vientos sus amables promesas, pero no llevaron consigo sino a mediocres talentos, con la única excepción de Mira de Amescua, que una vez en Nápoles se vio pronto alejado también de la corte virreinal.

Cervantes ha hecho de estas poco airosas maniobras de los Argensola uno de los episodios más importantes de su poema, cuando se excusa con Mercurio de llevar a los "Lupercios" la convocatoria a la lucha que se avecina. Se refiere a todo este asunto con palabras muy sopesadas: hágalo "otro más grato", "negociar", "no he de ser escuchado", que ambos hermanos tienen "la voluntad, como la vista, corta", y que por su causa se halla ahora con tan "pobre recámara", pues le entretuvieron por mucho tiempo con promesas vanas. Es todo un ejercicio de contención verbal, pero que en realidad suscita graves insinuaciones de ceguera y mala voluntad, mientras que aquello de llamarlos "Lupercios", jugando adjetivamente con lupus, supone una annominatio no poco vitrióiica ${ }^{23}$. Ambos hermanos dejan por esto de asistir en persona a la defensa del Parnaso, si bien sus obras se acreditarán como munición utilísima en la batalla, con lo cual el hilo puede tomar-

${ }^{22}$ Christóval Suárez de Figueroa, El Passagero, ed. R. Selden Rose, Bibliófilos españoles, Madrid, 1914, p. 425. Está hablando aquí de las supuestas gestiones previas para dedicarle una obra suya.

${ }^{23}$ En especial si se tiene en cuenta que ambos hermanos eran llamados comúnmente "los Argensolas" a secas. Lupercio era sólo el nombre de pila del mayor y Herrero García, en su intento de explicar la anómala denominación, estima que Cervantes aludía "a que Lupercio era el secretario de Estado del conde de Lemos, virrey de Nápoles, y el otro hermano, Bartolomé, iba a la rastra y en papel secundario"' (Viaje del Parnaso, p. 586). Como señala aquí el mismo dar un recado (según deseaba Mercurio que les llevara Cervantes) era entonces frase "excesivamente familiar" y de "cierto sentido confidencial malsonante". 
se por uno u otro cabo. Es obvio que Gervantes no desea cortar amarras con unos poetas a quienes por encima de todo admira y que, para colmo, continúan altamente encumbrados.

Aparte de su interés para la biografía cervantina, esta ilusión de los poetas encandilados con la nonata corte poética de Nápoles permite un atisbo profundo de la tensión humana de aquel momento literario. Fuera de toda perspectiva realista, el virreinato de Lemos ha dado paso en la imaginación de muchos a una insensata euforia. Con notable simpleza, se ha visto allí una solución bajada del cielo, como si dicho nombramiento tuviera por objeto el remedio de la poesía castellana y fuera a dar un final de cuento infantil a la imposible situación de los poetas. La capacidad seductora de este ensueño partenopeo se ha visto multiplicada por el desaliento imperante entre los hombres de letras y que, a modo de un sello del tiempo, siembra ahora en ellos la idea desesperada de abandonar la patria ingrata. Es el colectivo estado de ánimo que será objeto de un complejo análisis en El Passagero. Advertencias utilissimas a la vida humana, publicado en 1617 por Cristóbal Suárez de Figueroa (1571?-1639?), gran escritor semiolvidado y cercano en tantos aspectos a Cervantes. Rata precoz en abandonar el barco había sido Mateo Alemán, con su huida en 1608 a unas Indias en que sepultar su fama literaria ${ }^{24}$. El ingenio sevillano representaba, sin embargo, un caso peculiar y extremo, pues el gran señuelo es entonces Italia, que encandila a los poetas igual que las Indias a los codiciosos y a los interesados en poner tierra por medio. Italia, con una literatura muy hermanada, se antoja ahora como el ideal de lo que podría ser una España vividera y bien regida: una admirable razón de estado (se admite por todas partes) cuida allí de conservar a los hombres de valor y recompensa por encima de todo el saber y el ingenio ${ }^{25}$. Nápoles, en especial, es visto desde España como un paraíso de

24 Dicho desesperado recurso, en huida de la que se había vuelto una peligrosa fama literaria, se hace mucho más comprensible tras las serias acusaciones y amenazas de buscarle problemas con la Inquisición realizadas en 1605 por el autor de La pícara Justina. Véase Francisco Márquez VillanueVa, "La identidad de Perlícaro", Homenaje a José Manuel Blecua, Gredos, Madrid, 1983, pp. 423-432.

25 "Determiné salir de España, donde son poco estimados los documentos políticos. Es admirable la razón de estado italiana, pues conserva a sus naturales, a manera de nortes, en puestos firmes. Armas y letras dan conocidos grados de nobleza; los demás exercicios perdonen" (SuÁrez dE FigueroA, El passagero, p. 434). 
amor, poesía y buenas posadas: "Todos los que dexan aquel Reyno, ensalçan sus cosas y suspiran por boluerle a ver" 26 , testimoniaba Suárez de Figueroa. El ensueño de Italia para hombres de letras hastiados de la indiferencia española no dejó de brillar por mucho tiempo. En 1634, las Rimas humanas y divinas de Lope de Vega nos cuentan que su verdadero autor, el licenciado Tomé de Burguillos, marchó un buen día a Italia, donde se ha perdido para siempre su rastro poético.

El Viaje del Parnaso replantea hábilmente unos cuantos topoi de la más acartonada tradición académica en cuanto literaturisierung de aquel colectivo estado de desesperanza ${ }^{27}$. $\mathrm{Y}$ es entonces cuando hace su entrada en escena un personaje semi-fantástico, cierto poetón indigente de los muchos que malviven en la corte, llamado, por gran casualidad, "Cervantes", y a quien, por supuesto, hay que vigilar con la cautela que siempre requiere el dejo irónico de sus menciones en primera persona ${ }^{28}$. Años, desdichas y forzados ayunos no han extinguido en él la llamada jubilosa a la suprema experiencia poética del Me Parnasi raptat amor del Mantuano. ¿Por qué iba a ser él menos que aquel Caporali para dar un poco de respiro al alma, viajando por espacios fantásticos?:

Quisiera despachar a la estafeta mi alma, o por los aires, y ponella sobre las cumbres del nombrado Oeta.

Sólo que hay también el torcedor que suponen ilusiones muy humanas, pero de orden menos puro. Estimulado ahora por "los humos de la fama"' (I, 47) este otro habitante de la corte madrileña se anima a emprender la jornada con la idea de buscar, no

${ }^{26}$ Ibid., p. 35.

${ }^{27}$ Como observa Croce, el tema de tales visitas al Parnaso reflejaba también en Italia el desaliento escéptico de una literatura en cuesta abajo (op. cit., p. 127).

28 " Cervantes en primera persona no es una persona real y verdadera. Es un ser imaginario: elaborado, claro está, con elementos sacados de la experiencia del manco de Lepanto, pero engendrado por un "decir» específico y establecido como tal por la mirada del lector" (JEAN CANAVAGgio, "Cervantes en primera persona", $J H P h, 2$ [1977], 35-44). La sustitución del yo retórico del Viaje de Sannio por el yo existencial del Viaje del Parnaso, así como su distanciamiento del modelo picaresco son fundamentales para el mismo crítico en "La dimension autobiographique du Viaje del Parnaso", Actes du colloque international de la Baume-lès-Aix, 1979, Aix-en-Provence, 1980, pp. 171-184. 
ya en el ingrato terruño donde nadie es profeta, ni tampoco en Nápoles, sino en el remoto Parnaso, el supremo reconocimiento o corona de laurel que ahora se le niega:

Dije entre mí: si yo viniese a verme en la difícil cumbre de este monte, y una corona de laurel ponerme.

Semejante soñar con las cumbres y recompensas del Parnaso achata aún más la prosaica realidad que en aquellos días le abruma. La sola mención del adiós a "la humilde choza mía" figura como alusión muy clara a las vacas flacas que entonces corrían para el poeta ${ }^{29}$. Cervantes no necesita tampoco de muchos versos para su deprimente pintura de un Madrid cuyos únicos lugares memorables se hallan dedicados a la ociosidad y la mentira y al que por lo menos evitará, con su ausencia, el oprobio de morirse en él de hambre. Pobreza de la bolsa y del espíritu, los placeres negativos de la holganza y del cotilleo, así como el triunfo de la ignorancia en sus teatros, definen el cuadro argamasillesco y manchego de que aquel semi-desnudo "Adán de los poetas", $(I, 202)$ querría desintoxicarse con algunas brisas mediterráneas.

La navegación o Viaje en busca del Parnaso constituye el cuerpo central del poema. Lo que se ha venido describiendo como "catálogo" de elogios poéticos resulta ser, bien leído, un complejo panorama de la poesía española de aquel gran momento. ¿Elogios sinceros? Claro que ios hay, como los dedicados a Góngora, a Quevedo e incluso, con toda justificación y elegancia, a sí mismo, porque sin la centralidad del propio Cervantes dicha pintura quedaría objetivamente menoscabada de su adorno más esencial ${ }^{30}$. Pero

${ }^{29}$ No cabe aceptar fácilmente que el sentido de esa "choza humilde" se deba al deseo de Cervantes de dar allí una nota bucólica "sin intención especial de referirse a mayor o menor pobreza de su casa", como propone $\mathrm{HE}$ RRERo García en su anotación correspondiente (Viaje del Parnaso, p. 373).

${ }^{30}$ Responden sin duda los autoelogios de Cervantes a una necesidad de reconocimiento tan legítima como profundamente sentida, pero no dejan de hallarse igualmente sujetos a la dinámica lúdica determinada por otras constantes internas de la obra. No hay que olvidar el ejemplo de la Moria erasmiana, donde el recurso al autoelogio sirve como máxima prueba de su propia estulticia. El "poetón" del Viaje del Parnaso es también una especie de loco o persona medio trastornada que entona su propia alabanza. Tales autoelogios se hallan asimismo minados por la general hipoteca adoxográfica. El sentido basculante de lo allí dicho acerca de su soneto al túmulo de Felipe II ha sido 
después, tanto otro "elogio" neutro o muy calibrado, hasta dar en los legibles en doble sentido, como los de Miguel del Cid o Salas Barbadillo, y con desembocadura para colmo en las abiertas rechiflas contra los desdichados Lofraso, López de Ubeda, Arbolanches, Pedrosa y tantos otros. No hay si se va a ver rincón que no ofrezca allí su enseñanza o, al menos, un tema de estudio, porque esencialmente el Viaje del Parnaso constituye a la vez una gran obra de crítica literaria. Las notas de Miguel Herrero García aciertan, por ejemplo, al señalar su generosidad con los noveles, así como los repetidos vaticinios acerca de la carrera de poetas entonces en ciernes ${ }^{31}$, y hasta sonados acontecimientos como la final renuncia de Juan de Jáuregui a la jefatura poética de Lope. Contra tanto juicio derogatorio del Viaje del Parnaso, el lector de entonces y de ahora encuentra allí la inestimable oportunidad de recorrer los vericuetos de aquel inmenso mundo literario bajo la guía lazarillesca de nada menos que Miguel de Cervantes.

Una sabia economía, un juicio siempre certero y un cálido sentido humano van dejando en el fiel los más diversos aspectos de una literatura no teorizada, sino "vivida". Así los debidos agradecimientos, empezando por aquel fray Juan Bautista Capataz, sin duda un "cura liberal" de esos de siempre, que cubrió con su hábito mercedario la aprobación de las atrevidas Novelas ejemplares. También el recuerdo cariñoso de los amigos de los años sevillanos como Juan de Ochoa, Cristóbal de Mesa o Pedro de Medina Medinilla, este último desde hacía mucho en Indias. Y sin dejar atrás tampoco la cortesía pagada sin adulación a los cuatro "poetas señores" (Esquilache, Saldaña, Villamediana y Alcañices), en quienes (salvo el primero) se ve no cree mucho. No menos admirable su respeto al anonimato de Tirso y la mención puntual de otros distinguidos eclesiásticos a quienes, a su vez, censura por celar, vergonzantes, sus inclinaciones literarias "ante la turba vil del suelo"' $(4,249)^{32}$; al mismo tiempo querrían el ho-

señalado por Nicolás Marín, "Una nota al Viaje del Parnaso", Acero, 22 (1984), 201-220.

31 Herrero García llama la atención hacia sus acertados pronósticos acerca del desarrollo y carreras de las jóvenes promesas que en aquel momento no pasaban de ser, entre otros, Felipe Godínez, Luis Vélez de Guevara, el príncipe de Esquilache, Guillén de Castro, Francisco de Rioja, Antonio de Galarza, Diego Jiménez de Enciso y otros.

32 Cervantes se subleva contra el prejuicio que considera a la poesf́a como frivolidad o entretenimiento indigno de graves personas eclesiásticas o de encumbrados señores. Téngase en cuenta el caso del juego al anonimato por 
nor pero no el nombre de poetas:

Aquestas seis personas religiosas como están en divinos puestos puestas y en sacra religión constituidas, tienen las alabanzas por molestas que les dan los poetas, y holgarían llevar la loa sin el nombre a cuestas.

(IV, 325-330)

Están allí "casi" todos los que deben estar. No falta, al menos, ninguno de los grandes y es bastante probable que cierta cuña poética que suele ponerse a la cuenta de Quevedo resulte mucho más aplicable a Mateo Alemán ${ }^{33}$, dado cuanto hoy sabemos acerca de la que ya es preciso llamar también su "nueva biografía":

Este que el cuerpo y aun el alma bruma de mil, aunque no muestra ser cristiano, sus escritos el tiempo no consuma.

Cervantes hasta procura acordarse de algún poeta portugués ${ }^{34}$ para que toda la Península quede representada en la expedición de socorro al Parnaso. Ciertamente se echa de menos a Pedro Espinosa y su pujante escuela antequerana, en respuesta quizás de no haber incluido aquél a Cervantes en sus Flores de 1605 . Al mismo tiempo, había comenzado éste por saludar en bloque a los "fa-

el mismo fray Luis de León, estudiado por Dámaso Alonso, "Fray Luis en la "Dedicatoria" de sus poesías. (Desdoblamiento y ocultación de personalidad)"', Studia iphilologica et literaria in honorem L. Spitzer, Berna, 1958, pp. 15-30. También Rodrí́GUEz MARín, "La poca estimación en que eran tenidos los poetas"' (Viaje del Parnaso, apéndice 8).

${ }^{33} \mathrm{El}$ citado terceto suele considerarse introductorio del elogio y semblanza poética de Quevedo, que sigue allí a continuación (304-312). El texto es, sin embargo, bastante claro en cuanto a hablar, por separado, de dos poetas diferentes y el primero de los cuales se considera un nombre vitando, de acuerdo con su "no ser cristiano". Coinciden dichas señas con la pésima reputación personal de Mateo Alemán y dudas acerca de su ortodoxia en los años anteriores a su emigración a México. Estudio más detenidamente este problema en otro lugar.

34 Así el entonces casi desconocido Miguel da Silveyra, "por quien de Luso están ufanas / las musas"' (II, 175-176). 
mosos de Andalucía” (I, 334), como reconociendo que de ellos venía, bajo el caudillaje de Góngora, la más alta renovación poética.

Caso muy tratado con pinzas es el del ya virrey don Pedro Fernández de Castro, aludido a secas como "el conde" por Mercurio, en prueba indirecta de que Cervantes no lo absolvía tampoco de alguna responsabilidad en la conducta de sus secretarios los "Lupercios". Tal vez por enmendarlo un poco lo elogió al final no como hombre de letras, sino como gallardo participante de un torneo en Nápoles. Pero el que allí "falta" conspicuamente es el máximo “académico" Lope de Vega. Su entrada en la galera se produce a consecuencia de un extraño fenómeno atmosférico. Una súbita tormenta llueve sobre aquella multitud de poetas sin historia y cuyo lastre o peso muerto está a punto de echarla a pique. Una nube aparte dejó caer, poco después, a Lope de Vega:

Llovió otra nube al gran Lope de Vega, poeta insigne, a cuyo verso o prosa, ninguno le aventaja, ni aun le llega.

Cervantes compara semejante pedrisco de poetas con la generación espontánea de sapos y ranas por efecto de la lluvia. Gran es un elogio inflacionario y burlescamente prodigado a lo largo del poema $^{35}$ y ahora sabemos que dicha caída de las nubes ha de ser decodificada como punzante emblema alusivo a la mayúscula vanidad de Lope ${ }^{36}$. Tal vez debido a su dudoso ejemplo, toda aquella no invitada "poetambre" (II, 396) llena ahora los aires de versos insoportablemente melosos ${ }^{37}$. Mercurio, exasperado, decide pa-

${ }^{35}$ Maurino, art. cit., p. 44. Aplicado a diestro y siniestro a todo lo largo del poema, su marcado carácter irónico es puesto de relieve por usos como “Llenó del gran bajel el gran vacío / el gran Francisco de Rioja..." (III, 124-125).

${ }^{36}$ El complejo tinglado de alusiones ha cedido en esto al perspicaz análisis de Ellen Lokos, "El lenguaje emblemático de El viaje del Parnaso", Cervantes, 9 (1989), 63-74. El emblema y su pariente el jeroglífico constituían también parte importante de la cultura o entretenimientos de las academias.

${ }^{37}$ Sin género de dudas es una nueva alusión al efecto corruptor de Lope, cuya autocompasión y exhibicionismo sentimental le atrajeron rechiflas desde la misma época de su romancero juvenil, así como el remoquete (por llorón) de "Antón Llorente". Véase Francisco Márquez Villanueva, "Lope, infamado de morisco", en Lope: vida y valores, Universidad de Puerto Rico, San Juan, 1988, p. 309. 
sar a todos los advenedizos por un cedazo, para quedarse con los pocos buenos y arrojar al mar los "granzones". No se averigua la suerte final de Lope de Vega, pues el Viaje del Parnaso no vuelve a nombrarlo para nada y ha dicho ya bastante para todo el que quiera entender.

El incidente de Lope y el turbión de poetas suele interpretarse por los comentaristas como parte del bando enemigo, que las nubes conducen al ataque del Parnaso ${ }^{38}$. Dicho en otros términos, la academia de la Argamasilla ha estado a punto de anegar la nave apolínea y probablemente ha infiltrado en ella algo de su espíritu, pues a la hora de la verdad una veintena de poetas se pasarán en la batalla al bando atacante. Quede en claro que el socorro español incluye una multitud de pésimos poetas, que durante el viaje van, por ejemplo, haciendo versos a los riñones de sus damas o comparándose con toros agarrochados de amor. Mercurio hubo de negarse a embarcar en la playa de Valencia a un verdadero tropel de ingenios locales (probables subproductos de su $\mathrm{Aca}$ demía de los nocturnos) ${ }^{39}$, temeroso de que una vez llegados al Parnaso se alzaran por las buenas con él mismo. Incluso la turbamulta de los llamados y elegidos incluye a individuos que beben de bruces, como brutos animales, y se hallan dispuestos a portarse allí del modo más grosero:

Llegóse, en fin, a la Castalia fuente $y$, en viéndola, infinitos se arrojaron, sedientos, al cristal de su corriente.

Unos no solamente se hartaron, sino que pies y manos y otras cosas algo más indecentes se lavaron.

${ }^{38}$ Puede darse por típica la impresión de Herrero García: "Estas nubes borrascosas, preñadas de poetas malos, sorprenden a Mercurio. Cervantes no explica cómo estos poetas excluidos de la lista de Apolo, se presentan de improviso. Posiblemente eran los que iban a poner asedio al Parnaso, motivo de la movilización de los poetas buenos ordenada por Apolo" (Viaje del Parnaso, p. 524).

39 Una de las academias más activas, funcionó de 1591 a 1594, para reaparecer guadiánicamente en 1616 bajo el nuevo título de Los montañeses del Parnaso. Su clara especialidad fue la poesía erótica, sin que falten otros géneros académicos como los elogios burlescos ("Romance en alabanza de la avellana" de Matías Fajardo, "Redondillas en alabanza de los alcahuetes" de Hernando Pretel, etc.), alabanzas en tercetos de todo el elenco académico, etc. Se conserva su producción en Pedro Salvá y Francisco Martí y Grajales, Cancionero de la academia de los Nocturnos, 4 vols., Valencia, 1905-1912. 
¿Cuál es en todo esto el supuesto papel del "poetón" Cervantes? Se apresura éste a declarar en más de una ocasión su no ser responsable de la lista de poetas convocados por Apolo. Por su parte se limita a poco más que apostillarla para Mercurio, que no conoce a ninguno ni anda muy puesto en cosas de literatura, pero incluso en esta modesta consejería se ve acusar de arbitrario y parcial de los colegas que por su cuenta y riesgo se presentan ante el Parnaso en una gruesa nave mercante. Cervantes ni siquiera niega que, en parte, puedan tener alguna razón y por ello se limita a pedir a Apolo los milagros que él, como humano, no puede realizar. El elenco inicial de poetas era "casi infinito" e incluía a toda suerte de "yangüeses, vizcaínos y coritos" (I, 333), es decir, mucha gente rústica y semibozal en la lengua castellana. Pecaba aquel indiscriminado llamamiento al Parnaso de lo mismo que se proponía corregir y de esta forma introduce desde el principio un testimonio firme de la irremediable situación de la poesía, a la vez que de la alocada incompetencia de Apolo en el terreno de sus más inmediatas responsabilidades. En cierto momento, el joven dios confiesa su escaso acierto en la convocatoria de los poetas y Cervantes añade, sarcástico, que ni aun la divinidad puede prescindir de la experiencia:

La Prudencia, que nace de los años y tiene por maestra la Experiencia, es la deidad que advierte destos daños.

(VII, 124-126).

La crítica ha considerado siempre fundamental el tratamiento burlesco a que el tema mitológico es sometido en el Viaje del Parnaso. Puesto, por lo común, a cuenta de un rasgo de época, dicha burla era ya conspicua en la Moria erasmiana y en el manejo general de los temas antiguos por el Baldas de Folengo. Ante el poema de Cervantes bromeaba Rodríguez Marín si toda aquella gentualla de dioses se calificarían allí de alucianados o avelazcados ${ }^{40}$, si bien prevalezca en conjunto su inevitable asociación con la sensibilidad de Velázquez en obras como Marte o La fragua de Vulcano. La realidad era que tales libertades resultaban también muy propias de los escarceos académicos y el tema del Olimpo burlesco lo ha-

40 Viaje del Parnaso, p. lxi. Claro que, como también se advierte aquí (p. 65), Velázquez era a la sazón un aprendiz de catorce años en el taller de sevillano de Pacheco y son sus cuadros los que han sido en esto influidos por la literatura (Gervantes, Quevedo) y no al contrario. 
bía extremado ya Juan de la Cueva en su Viaje de Sannïo, basado en el tópico de la pobreza del poeta (Sannio lo es de los buenos) y escrito en $1585^{41}$. Lo que sí hacía allí Cervantes era dar una nueva dimensión al bromazo mitológico cuando usaba en las alturas del Parnaso aquella lengua de jaques y tahures, con la cual venía minando tan creadoramente los géneros "serios" desde los últimos años de su etapa sevillana. Y quede en este momento a un lado como tema merecedor de estudio aparte.

En el Viaje del Parnaso Cervantes hace de Mercurio un simpático jayán aficionado a la guitarra, de Venus una moza del partido y de Apolo un joven amable, si bien perdidamente superficial. No se da en esto tregua ni cuartel: se describe a cierta sirena con facha de verdulera y a Neptuno como un viejo de malas pulgas, coronado de dos lampreas y con las barbas incrustadas de mejillones, cangrejos y otros mariscos. Cierto que encuentra en el Parnaso a la Poesía en todo su virginal esplendor, pero también, cerca de ella, a la triunfante Vanagloria, con su enorme vientre preñado de vientos. Nadie da muestras de entender la situación angustiosa de las Letras ni hace allí nada útil para remediarla. Hay en aquellas alturas demasiada gente de poco más o menos

${ }^{41}$ A. WulfF, Poèmes inédits de Juan de la Cueva. Publiés d'après des manuscrits autographes conservés à Seville dans la Bibl. Colombine, Viage de Sannio, Lund, 1887. Extrait de l'Annuaire de l'Université de Lund, Lunds Universitets Arskrift, t. 23. Sorprende Herrero García al suponer una absoluta originalidad por parte de Cervantes en el tema de la burla del Olimpo: "En el aspecto mitológico, Cervantes se encontraba ante un prestigio intacto, abroquelado por la áurea armadura de la antigüedad clásica, divinizado por el Renacimiento e idolatrado por la poesía moderna [...] subsistía en pie, inatacable y desafiador, el orden mitológico"' (Viaje del Parnaso, p. 14). El tratamiento degradado (del que sólo se salva la personificación de la Poesía) y sus antecedentes es estudiado por CoRrea, "La dimensión mitológica del Viaje del Parnaso de Cervantes". Se ha señalado, por lo demás, el precedente de la burla mitológica en el $R o$ mancero general, cuyo 206 "Yo, Apolo dios de la ciencia" se queja de la multitud de poetas que ahora concurren al Parnaso, con gran detrimento de sus flores, sembrados y fuentes; se habla allí de los poetas que "a escapar de borricos / sin duda serán badajos" y de cierto examen de ingreso que habrá que poner en práctica "porque nuestra academia / no se pueble destos trasgos" (Romancero general, ed. A. González Palencia, CSIC, Madrid, 1947, t. 1, 141). En otro (261) relacionado con ciertos "académicos del Tajo" se cuenta cómo "en un monte, dixo Ovidio, / que dio una coz un caballo, / de que ha salido una fuente, / donde beben tantos asnos" $(1,172)$. El tema de Apolo y sus jocosas relaciones con los poetas continuó por largo tiempo como favorito de academias carnavalescas, como las estudiadas por HANNAH E. BERGMAN, "El «juicio final de todos los poetas españoles muertos y vivos" (ms. inédito) y el certamen poético de 1638', BRAE, 55 (1975), 551-610. 
y que no piensa más que en frivolidades (igual que en la corte de Madrid). Reina allí un aire de bullanga y de prosaica claudicación: entre las Horas que como "doncellas bailadoras" salieron a solemnizar el recibimiento de los poetas no dejaba de haber también algunas "medio rotas" (III, 340). Pero lo peor de todo es que el aturdido Apolo ni siquiera cae en la cuenta de ofrecer algo que cenar a los poetas que vienen en su socorro. La excelsitud del Parnaso queda pronto anegada por este camino en un baño de general prosaísmo. Se anota la dieta que mantiene en equilibrio las delicadas tripas del caballo Pegaso (que ni se "estriñe" ni "se va"), así como la habilidad de la musa Urania para transformar los excrementos del mismo en remedio infalible contra los váguidos de cabeza que con demasiada frecuencia suelen afligir a los poetas. La subida a las cumbres del Parnaso revela un mundo benignamente similar al hallado por Don Quijote tras su descenso a la cueva de Montesinos ${ }^{42}$. Ambas aventuras (escritas, además, en estrecha cercanía cronológica) materializan "extramundos" de signo lucianesco y guevariano, por completo locos y sin arreglo, a la vez que enderezados a infundir en el lector una desencantada conciencia del artificio literario ${ }^{43}$.

La broma o irreverencia mitológica (como en el Quijote la caballeresca) es pronto puesta al servicio de finalidades más significativas. Una vez llegado Cervantes al Parnaso comprueba con desaliento que Apolo tampoco le distingue ni reconoce, mientras que extrema sus deferencias con los poetas de rango nobiliario y les ofrece los mejores asientos. Cervantes se queda sin poder sentar-

42 Véase, de entre una extensa bibliografía, G. FRY, "Symbolic action in the episode of the cueva de Montesinos", $H, 48$ (1965), 468-474. PETER N. DunN, "La cueva de Montesinos por dentro y por fuera", $M L A, 88$ (1971), 268-273. Helena Percas de Ponseti, Cervantes y su concepto del arte, Credos, Madrid, 1975, cap. 7, "La cueva de Montesinos, el lenguaje como creación"'. Augustin REDONDO, "El proceso iniciático en el episodio de la cueva de Montesinos del Quijote, I', 13 (1981), 47-61. E. C. RILEY, "Metamorphosis, myth and dream in the cave of Montesinos", Essays in honour of Frank Pierce, Dolphin Books, Oxford, 1982, pp. 105-119.

${ }^{43}$ Como explica Alban K. Forcione en relación con la cueva de Montesinos: "The irreverent metamorphoses of such models produce the effect of a dismemberment of form of the type which is traditional in satirical literature with its cultivation of all devices which bring about narrative disorientation and force the reader into a stance of detachment, ranging from repugnance to amusement, as he contemplates the objects of the fictional world" (Cervantes and the mystery of lawlessness. A study of "El casamiento engañoso" $y$ "El coloquio de los perros", Princeton University Press, Princeton, 1984, p. 50). 
se, en medio de tantas mediocridades, y cuando el distraído dios le aconseja que lo haga sobre su capa ha de recordarle que, por su pobreza, carece de ella. Con la paciencia casi perdida, habrá de refrescarle la memoria con un resumen de su larga vida literaria y un catálogo esencial de su obra. Apolo deberá saber de una vez que no es ninguna cuestión de vanidad, pues se precisa un mínimo de éxito y reconocimiento ${ }^{44}$ para no ser despreciado de envidiosos e ignorantes. No figura tampoco Cervantes entre los tres poetas que fueron allí mismo coronados. Los que en el Parnaso pelearon como buenos recibieron un premio simbólico de flores y algunas perlas, pero tampoco parece que él mismo se hallara entre los tan parcamente recompensados. Hay, al otro extremo, una inflación de honores, pues Apolo envía tres coronas de laurel para vates de la Península, más otras tres para los de Nápoles ${ }^{45}$, y algunos "envidiosos" quedan perplejos acerca de cómo puede España poseer nada menos que nueve testas laureadas.

Es sólo tras esta inmensa desilusión cuando el largo periplo al Parnaso asume su pleno sentido y resulta clave, a la larga, para una suprema intelección de la poesía que Cervantes desea legar en testamento a sus más fieles lectores. Porque el Viaje del Parnaso tiene también un retorno que se realiza, como había de ser, a la callada y sin la teatralidad ni algazara de la galera alegórica. El discurso de bendición o despedida de la Poesía da paso a la presencia de Morfeo (el género de los viajes al Parnaso era de los más soporíferos), quien sume en profundo sueño a los excombatientes para el callado viaje de vuelta a sus tierras. Cervantes hace en este rápido retorno breve escala en un Nápoles para él cargado de recuerdos juveniles y poco después se encuentra de nuevo en su "antigua y lóbrega posada" de la corte, donde se arroja exhausto sobre el lecho, "que cansa, cuando es larga, una jornada"' (VIII, 457).

${ }^{44}$ La justificada base autobiográfica de tal afán de público reconocimiento fue establecida por Elias L. RIVErs, "Cervantes' Journey to Parnassus", MLN, 85 (1970), 243-248. Ampliado acerca de éste y otros aspectos del poema por Jean Canavaggio, "La dimension autobiographique du Viaje del Parnaso", p. 172.

45 Según la conjetura de Astrana Marín los coronados en el Parnaso serían Quevedo, Góngora y Espinel. Los napolitanos, los hermanos Argensola y el conde de Lemos o el de Villamediana. Las coronas enviadas a España serían destinadas a Francisco de Aldana, Francisco de Figueroa y Fernando de Herrera (Vida ejemplar y heroica. . ., t. 7, 131-132). La selección de este último grupo hace sin embargo escaso sentido. 
Semejante retorno de un Cervantes, molido y quebrantado tras el decepcionante viaje, a su miseria madrileña de siempre podría ser interpretado, en el contexto de una lectura romántica, como el cuadro tristísimo de una derrota definitiva: no hay laurel ni Parnaso que valga para el poeta, lo mismo que no hay más que estacazos para el caballero andante. Y sin embargo, como aclaran también aquellas páginas finales, el poeta que viajó al Parnaso no es ahora ningún pobre amargado, maduro para el láudano o el pistoletazo en la sien, sino un ser más que nunca sabio y en paz con su vida y con su arte. Es claro que Cervantes no va a despedirse del mundo con un mensaje de renuncia ni de odio a la poesía. Nos dirá, por el contrario, que la amemos, pero no como un trasto casero a lo argamasillesco ni como una entelequia erudita a la italiana, sino tal como ella es o como, mejor dicho, puede la poesía "servir" o "valer" para los hombres.

La literatura de ficción había tenido siempre como uno de sus pilares el relato de un viaje de búsqueda y prueba cuyo distanciamiento paródico puede considerarse una de las más decisivas constantes de la tarea cervantina ${ }^{46}$. El Viaje del Parnaso se inserta muy a las claras en la tradición de la jornada a un extramundo que desde la Odisea era uno de los grandes temas épicos. Destinado a sobrevivir bajo el gran artificio medieval de la "visión" o su variante el "sueño", había sido utilizado por el mismo Dante como base de su Divina Commedia ${ }^{47}$. Cervantes lo maneja, desde luego, dentro de un tratamiento paródico que tampoco revestía en sí mayor originalidad. Ariosto, con la eterna errabundez de sus paladines y en especial el viaje de Astolfo a la luna, así como Rabelais, con la visita de tantos lugares estrafalarios en el Tiers y en el Quart livre, son en esto los ejemplos y precedentes imprescindibles. Habían hecho ambos de las inauditas correrías instrumento predilecto tanto para el repudio de caducos valores medievales como para una autocrítica del humanismo, realizada desde la más profunda entraña de éste. Dicho nuevo concepto del viaje como mock epic equivale en realidad a una lente satírica y desmitificado-

${ }^{46}$ E. C. RILEY, "Cervantes: a question of genre", Mediaeval and Renaissance studies on Spain and Portugal in honour of $P . E$. Russell, Society for the Study of Medieval Languages and Literature, Oxford, 1981, p. 76.

47 Rodríguez Marín identifica en sus anotaciones tres ecos directos de la Divina Commedia. Es probable que el saludo de Mercurio, "¡Oh Adán de los poetas! ¡Oh Cervantes!” (I, 202), derive del "O degli altri poeti onore e lume", como sugiere F. D. Maur Ino, "El Viaje de Cervantes y la Commedia de Dante", KFLQ, 3 (1956), 7-12. 
ra de las últimas realidades humanas. La misma mecánica del periplo revelador de un mundo absurdo, situado en ninguna parte e invariablemente socavado por el prosaísmo socarrón, causa también el vaivén de regreso a una aprehensión lúcida de la realidad, no ofuscada ya por el espejuelo escapista de ensueños utópicos ni paraísos de guardarropía. Hasta llegar a Dante, el viaje extraterreno, con su cortejo de aspectos iniciáticos, tenía por objeto la epifanía de una nueva conciencia con miras a la decisiva consolidación del mundo interior del protagonista. Ahora, por el contrario, la voz narrativa de estos viajes paródicos del Renacimiento no se ve confirmada sino en la relatividad, limitaciones e incongruencias del fenómeno humano, tan asediado en la época de dogmas e intolerancias. Basándose en Ariosto y Rabelais, pero sin extenderse a Teófilo Folengo (tan decisivo para Cervantes), Elizabeth A. Chesney ${ }^{48}$ ha estudiado con gran perspicacia este lozano brote de la mejor literatura del Renacimiento, para el cual propone la terminología genérica de "contraviaje" (countervoyage).

No quiere decir esto que el Viaje del Parnaso tenga por qué invocar ninguna intertextualidad inmediata con el Orlando furioso, y menos aún con las "prouesses gigantales" de Rabelais. El concepto de "contraviaje", como péndulo oscilante entre la locura y la cordura, no representa más que una nueva objetivación de la dialéctica de la paradoja como piedra angular del humanismo cristiano en su recorrido desde el De docta ignorantia del Cusano a la Stultitiae Laus de Erasmo. El género (o mejor "contragénero") no existiría sin el concepto de adoxografía o elogio irónico de raíz lucianesca ${ }^{49}$, conforme al modelo sobre todo de Erasmo en aque-

${ }^{48}$ CHESNEY, The Countervoyage of Rabelais and Ariosto: a comparative reading of two Renaissance mock epics, Duke University Press, Durham, 1982. El género venía implicando, entre sus características más básicas, la pérdida del respeto a los dioses olímpicos (p. 62 ss). Sobre las relaciones de Cervantes con Ariosto y Folengo, Francisco Márquez Villanueva, "Teófilo Folengo y Cervantes", en Fuentes literarias cervantinas, Gredos, Madrid, 1973.

49 Para sus orígenes y tradición véase ARThur H. PEASE, "Things without honor", $C P h, 21$ (1926), 27-42, A. E. MALLOCH, "The techniques and function of the Renaissance paradox", SPh, 53 (1956), 191-203; HENRY K. MILLER, "The paradoxical encomium, with special reference to its vogue in England 1600-1800", MPh, 53 (1956), 145-178. Bibliografía obligadamente complementaria son aquí los libros de B. C. Bowen, The age of bluff. Paradox and ambiguity in Rabelais and Montaigne, Urbana, 1972, y Rosalie Colie, Paradoxia Epidemica, Princeton University Press, Princeton, 1976. Para Cervantes en particular, "El mundo literario de la paradoja" y "La paradoja cervantina”, en Francisco Márquez VillanueVa, "El caballero del Verde Gabán 
lla última. Ninguna sorpresa aquí para la crítica cervantina, que pisa en esto sobre terreno firme y no tendrá, seguramente, mayor dificultad para reconocer el Viaje del Parnaso como digna corona de una meditación sobre la paradoja que ha cubierto la gran etapa de madurez creadora del maestro ${ }^{50}$. La única ruptura de Cervantes respecto de esta modalidad genérica del "contraviaje" es de orden referencial, pues mientras Ariosto, Rabelais y en parte también Folengo apuntan a la diana del periplo como signo de las inquietudes intelectuales de los nuevos tiempos (centradas en los descubrimientos geográficos) y de las reservas que éstos les merecen, el "poetón ya viejo" (VIII, 409) no acompaña en esto a Epistemón ni a Astolfo por las regiones de una delirante geografía moral. Para Cervantes la verdadera mira de sus desvelos no puede ser (harto "académicamente") otra que la literatura.

La finalidad al fin y al cabo interesada que predomina en la jornada al Parnaso de aquel "Cervantes" no coincidió nunca del todo con el puro ideal virgiliano de una penosa subida del poeta, camino de la transparencia de una cumbre en que encontrarse consigo mismo. Dicho carácter se diluye aún más cuando al llegar a Cartagena encuentra el peregrino la orden de movilización de Apolo a un ruidoso, aunque irreprochable, episodio bélico. Semejante ida al Parnaso no va a ser una ascética subida, sino una llana excursión marítima y, en lugar de búsqueda solitaria, se perfilará como el episodio vocinglero y multitudinario del crucero marítimo. Traspuesto a otro lenguaje, equivale a decir que este Viaje del Parnaso no es virgiliano sino lucianesco. El ámbito narrativo de la galera y su prolongación en el "nombrado Oeta" (I, 31)

y su reino de paradoja”, en Personajes y temas del Quijote, Taurus, Madrid, 1975, pp. 208-216.

50 Véanse la bibliografía y conclusiones relativas a estos aspectos de Cervantes en Francisco Márquez Villanueva, "La locura emblemática en la Segunda parte del Quijote", en Cervantes and the Renaissance, ed. Michael D. McGaha, Juan de la Cuesta, Easton, PA, 1980, pp. 87-112. Del mismo autor "La buenaventura de Preciosa", NRFH, 34 (1985-1986), 741-768. MANUEL DurÁN, "El Quijote a través del prisma de Mikhail Bakhtine: carnaval, disfraces, escatología y locura", en Cervantes and the Renaissance, pp. 71-86. Augustin REDONDO, "Tradición carnavalesca y creación literaria. Del personaje de Sancho Panza al episodio de la ínsula Barataria en el Quijote", $B H i, 80$ (1978), 39-70. Del mismo autor, "El personaje de don Quijote: tradiciones folklóricoliterarias, contexto histórico y elaboración cervantina", $N R F H, 29$ (1980), 3659. "La folie du cervantin Licencié de verre (traditions, contexte historique et subversion)", en Les visages de la folie (1500-1600), ed. A. Redondo et A. Rochon, Publications de la Sorbonne, Paris, 1981, pp. 33-44. 
se define como un espléndido universo de locos que, en continuo remolino, termina por subirse a la cabeza de cuantos se acercan a contemplarlo. No en vano hacia su final los "váguidos"' del cerebro de los poetas, y hasta del mismo Apolo, se vuelven una mención obsesiva. El acercamiento del agua a la idea de locura ${ }^{51}$ sigue siendo allí básica y funcional. La alegría gratuita de la demencia preside tanto el viaje como los retozos de los poetas en el Parnaso, por una vez "de gusto llenos y de angustia faltos" (III, 294). La galera apolínea acota un reino alienante a modo de nueva abadía de Théléme, cuyos pasajeros viven el contento de darse sin tino a las respectivas manías. Los hay que van desnudos, mientras otros se arropan en hábito de romeros. Descuidados de pagar matalotaje y cada uno allá con su tema, todos componen y recitan la magna algarabía de sus versos. El espíritu de jolgorio cunde por todas partes y no hay tampoco límite para la alocada imaginación festiva: se levantó gran algazara con la idea de arrojar al mar a Lofraso como víctima propiciatoria contra los peligros de Escila y Caribdis, pero Mercurio, que impera en la galera sentado sobre seis resmas de papel, prefiere nombrarlo cómitre para que gobierne a la chusma con un rebenque hecho de sus temibles metros. Salvo por sustituir a locos musicales por locos poéticos, tenemos aquí la conocidísima iconografía del Narrenschiff5", que por primera vez navega la "aunque azul, líquida plata" (I, 151) del Mediterráneo y que, por fuerza, sólo podrá rendir viaje en una Narragonia como tantas otras.

Lo mismo que muchos de los episodios más locos de Ariosto y Rabelais ocurren también con motivo de largos viajes marítimos, el encuadre semiológico del "contraviaje" impone una manipulación creadora del personaje en que asienta una voz narrativa, forzada a subdividirse así como a distanciarse de la del autor.

51 "Pero a todo esto, el agua agrega la masa oscura de sus propios valores; ella lo lleva, pero hace algo más, lo purifica; además, la navegación libra al hombre de la incertidumbre de su suerte; cada uno queda entregado a su propio destino, pues cada viaje es, potencialmente, el último. Hacia el otro mundo es adonde parte el loco en su loca barquilla; es del otro mundo de donde viene cuando desembarca" (Michel Foucault, Historia de la locura en la época clásica, FCE, México, 1967, p. 19). Cervantes permanece fiel a la valoración negativa del agua, como anota Michèle Gendreau-Massaloux, "Une barque enchantée et quelques meuniers (Don Quichotte de la Manche, $\mathrm{II}^{\mathrm{e}}$ partie, ch. 29)", Imprévue (1978), 115-121.

52 Véase para el autor y la obra EDwin H. ZEYDEL, Sebastian Brant, Twayne, New York, 1967. 
En cuanto ser vivo que es al mismo tiempo testigo y dueño de la varita mágica, dicho personaje se halla atrapado entre dos tipos de realidad, lo mismo que entre los dos extremos o cornua de la paradoja. Su papel consiste en mostrarse igualmente comprometido y capaz de funcionar en ambos planos, cosa sólo al alcance de alguna modalidad de loco lúcido o sucesión seriada (como en el Quijote) de dicho tipo de máscara. En el caso del Viaje del Parnaso esa voz narrativa (es decir, su particular "Cide Hamete") encarna en la figura semibufonesca de cierto poeta hambriento, donosamente rebautizado allí como Miguel de Cervantes. Se va con esto un paso más allá de las figuras y semiautorretratos de éste como ridículo vate fracasado iniciada en los Entremeses ${ }^{53}$. Porque ahora escuchamos también, para colmo, a un desdichado poetastro, que no se hace ilusiones acerca de sí mismo y sueña por eso en remediar tanto su esterilidad como su indigencia con alguna fórmula mágica:

Pues descubriendo desde allí la bella corriente de Aganipe, en un saltico pudiera el labio remojar en ella,

y quedar del licor suave y rico el pancho lleno, y ser de allí adelante poeta ilustre, o al menos magnífico.

En el seno de una clara latencia bufonesca, el "Adán de los poetas"' (I, 202) va marcado por la heterodoxa indumentaria del carecer de capa (es decir, una doble virtualidad de desnudez), así como también por este abordaje carnavalesco en que la falta de dotes poéticas se resuelve con la materialidad de henchir el "pancho" de las aguas creadoras. Dicha figura de donoso "loco" centra el interés polarizador que el Viaje del Parnaso muestra en el complejo fenómeno literario del poetastro. Lo mismo que la Argamasilla daba pie para un recorrido tipológico de los bajos fondos académicos (piratas, pesados, paniaguados, caprichosos, burladores, seres ambiguos), el Viaje da entrada en diversos momentos a la misma clase de estereotipos negativos. Así el mocito imitador de Ganimedes, el paje que se cree llamado a la gloria poética, el estudiante que escribió una comedia de gran aparato, el "chacho

${ }^{53}$ Mary Gaylord Randel, "La poesía y los poetas en los Entremeses de Cervantes", ACerv, 20 (1982), 173-203. 
necio"' (II, 95) especialista en viles sátiras o aquel don Quincoces que resume a los linajudos que, tras ensartar cuatro rimas, se llenan de humos poéticos ${ }^{54}$. Los tercetos del Viaje del Parnaso establecen una brillante gradación léxica de subtipos del poetastro algo similar a la de los nombres de la alcahueta en Juan Ruiz e incluye a los madrigados, los tiernos, los godescos, los cueros, los zarabandos, los alfeñicados, los mellfluos, los sietemesinos, los lagartijeros, los a cantimplora acostumbrados, los monas, los no fénices sino fenices (por "fenicios", en rima con Alcañices), los fríos, los frescos, los calurosos y los poetísimos. Es claro, por lo demás, que donde Cervantes empieza por proclamarse poetastro, nadie podrá considerarse allí otra cosa ni darse tampoco por ofendido. Su lector ha sido llevado de esta forma a lo más denso de una perspectiva adoxográfica, cuya consecuencia más inmediata es la hipoteca que desde ese momento grava a su catálogo de poetas y juicios literarios. Nada más ingenuo, por lo mismo, que el tomar como Evangelio y verdadera confesión del autor aquel famoso y malhadado terceto en que estriban todos los repetidísimos juicios acerca del "Cervantes como poeta'":

Yo, que siempre trabajo y me desvelo por parecer que tengo de poeta la gracia que no quiso darme el cielo.

Quien así habla no es, claro está, sino un poeta muy seguro de sí y en trance de solicitar el homenaje requerido a su maestría en unos momentos particularmente afortunados. Válidos tal vez si se toman por separado, los encomios dan paso en conjunto a su eventual lectura bajo una sorna en contrario o adoxográfica que, de nuevo, asimila el Viaje del Parnaso a un dilatado vejamen académico. Todo es, en suma, el mismo juego de puertas batientes que en pequeño ilustra el llanto por la final derrota "de las $\mathrm{Mu}$ sas del limpio Tagarete"' (VII, 353).

El Viaje del Parnaso constituye por tanto un nuevo y muy serio grito de alarma ante la amenaza del academicismo argamasillesco. Se halla éste representado por un mismo vulgo de poetas romancistas, trovadores o trovistas (IV, 515), improvisadores y malos

${ }^{54} \mathrm{El}$ carácter genérico de tales personajes viene confirmado por el fracaso y especulaciones de los anotadores para identificarlos con algún poeta conocido. 
comediógrafos en trance de anegar con sus locuras la experiencia literaria española. Cervantes separa allí, como la zaranda de Mercurio en la galera, a los garcilasistas de los timonedas (VII, 294) y a los latinos de los poetas de romance (VIII, 106 y 109). Los romances en particular van como chusma (I, 250) forzada al remo en la galera. Cervantes reniega de los que escribiera en su juventud y en particular los de tema morisco se muestran arma temible de los atacantes al Parnaso. Esto último es como señalar con el dedo a Lope, igual que al referirse a las redondillas como sólo buenas para la "parlera" racamenta (I, 271) de la nave, pues no hay que olvidar que desde su Isidro de 1599 pretendía aquél convertirlas en piedra angular de su teorización de un Parnaso madrileñista, totalmente independizado de Grecia y su lengua ${ }^{55}$. Herejía, por tanto, en preludio de la del Arte nuevo y si cabe aún más desaforada.

Pero incluso estas críticas se hallan a su vez relativizadas y su burla mitológica dista de ser otra cosa que la lección de sensatez que más necesitan los poetas de su tiempo. El viaje a la locura del Parnaso lleva consigo la dinámica inversa de una recuperación de la perspectiva en su vuelta a un estado de equilibrada sensatez. El Cervantes que vuelve a Madrid ha superado claramente la etapa "surrealista" o "goyesca" (en realidad "Merlín Cocaio") de su discurso argamasillesco de 1605 , lo mismo que la desesperación personal del capítulo primero de este su último poema. Su fe en la poesía se muestra más firme que nunca y su contemplación cara a cara de la misma constituye la única experiencia íntegra y positiva de su visita al Parnaso. Se materializa en aquella visión la figura de origen emblemático e icónico con que Cervantes viene imaginando a la Poesía como una hermosísima donce$1 \mathrm{la}^{56}$ asistida (conforme a un ideal neoaristotélico) de todos los sa-

\footnotetext{
55 Francisco Márquez Villanueva, "La axiología del 'Isidro' ", en Lope vida y valores, pp. 99-106.

${ }^{56}$ El sentido del símil fue ya comentado por Américo Castro, El pensamiento de Cervantes, Noguer, Barcelona, 1972, pp. 42-43. Consideraciones de interés acerca del mismo en GEORGES GÜNTERT, " 'La gitanilla' y la poética de Cervantes", $B R A E, 51$ (1972), 107-134. Para el aspecto doctrinal de los cuatro elogios de la poesía bajo la metáfora o alegoría de la hermosa doncella, E. C. RILEY, “Teoría literaria”, en Summa Cervantina, ed. J. B. Avalle-Arce y E. C. Riley, Tamesis, London, 1973, pp. 299-300. Para la presencia de la misma idea en el Quijote, Francisco Márquez Villanueva, "El caballero del Verde Gabán y su reino de paradoja", pp. 190-195. La base iconográfica de la personificación de la poesía (Petrarca, Ripa) es mencionada por Correa, "La dimensión mitológica del Viaje del Parnaso de Cervantes", p. 188.
} 
beres y ciencias. Al contrario que Apolo, abraza esta "universal señora" (VIII, 190) sin distinción a los combatientes victoriosos y les dirige tan breves como sabias palabras. Primero, el agradecimiento por haberla salvado de caer en manos viles e incompatibles con su honesta pobreza. No puede, por lo demás, ofrecerles ningún premio de orden material. El Parnaso, les dice, carece de minas de metales preciosos y abunda sólo en aguas inspiradoras y salutíferas. Lo más decisivo es que, lejos de invitarlos a quedarse allí con ella, los exhorte a que permanezcan a su servicio tras su vuelta al suelo patrio. Mucho menos les hablará para nada de academias. Como tampoco condena la riqueza, ni los fuerza a huir de ella, su consejo es que vuelvan a pisar las arenas del aurífero Tajo y, sobre todo, que pasen allí muchas "dulces horas de pesar ajenas" (VIII, 213), bajo el inconfundible y noble pabellón de la herencia garcilasiana.

Las razones de la Poesía son una llamada a la realidad y un bálsamo contrario a tantas competencias y asperezas satíricas como en esos años envenenan la vida literaria española. No tiene, pues, la poesía nada que ver con el reconocimiento material ni con la fama, cuestiones pertenecientes a la relatividad imperfecta de todas las cosas humanas. Apolo respondió con sequedad a las quejas del que todavía era un poetastro ansioso de hacer fortuna: "tú mismo te has forjado tu ventura" (IV, 79)57, y es tal vez lo más acertado que alcanza a decir en todo el poema. La poesía es, antes que nada, y en sí misma, la recompensa inestimable de un inmenso y duradero goce. El Viaje del Parnaso objetiva en esto el discurso sapiencial sobre la poesía con que La gitanilla se distanciaba de tanta quejumbre tópica:

- Con todo eso - respondió Preciosa, he oído decir que es pobrísima, y que tiene algo de mendiga.

- Antes es al revés - respondió el paje- porque no hay poeta que no sea rico, pues todos viven contentos con su estado, filosofía

${ }^{57}$ Eco del aforismo estoico Quilibet faber propriae fortunae, era a la vez convicción favorita de Cervantes en los últimos años de su vida. "Cada uno es artífice de su fortuna" en el Quijote (II, 66). Expresiones similares en Persiles (II, 13). Véase nota de L. A. Murillo en su edición, Don Quijote de la Mancha, Castalia, Madrid, 1978, t. 2, p. 541. El Viaje del Parnaso tampoco oculta que la abyección literaria y moral ha sido también causante de la triste situación de los poetas, según Jordi Gracia García, "Intención y crítica del Viaje del Parnaso: en torno a la adulación y la vanagloria", Anthropos, 1989, núms. 88-89, p. 81 . 
que alcanzan pocos. ¿Pero qué te ha movido, Preciosa, a hacer esta pregunta? ${ }^{58}$

El poeta que volvió del Parnaso tan pobre como se fue es ahora, por lo menos, un discretísimo profesional, dispuesto a sazonar todo buen momento de su vida en el oficio con una dosis de socarronería. Clichés aparte y tomado objetivamente, hasta "es discreto el vulgo de la corte, / aunque le toca la común miseria" (VII, 320-321), por lo cual, a veces, hasta es capaz de distinguir entre buenas y malas comedias. La vida literaria del poeta digno del nombre puede verse de este modo como una ininterrumpida cadena de goces. El Cervantes de vuelta de tantas amargas y allí harto visibles realidades no está, decididamente, por los aspavientos, ni se considera menos que afortunado por su destino de poeta. Sin concesiones a picarescas ni a pedanterías de académicos "leyentes con letura" (I, 100), las primeras páginas del poema habían trazado ya una deliciosa imagen de los poetas como seres que, captados por una existencia en los confines de mundos interiores e imaginarios, "sobre el convexo van de las esferas"' (I, 84) y viven la continua maravilla de cuanto la fantasía les ofrece en cada instante. Nada menos práctico, pero nada también menos "romántico" ni académicamente "parnasiano"' que la envidiable libertad de estos seres no santos ni demonios, sino un poco absurdos e imposibles:

Llorando guerras o cantando amores, la vida como en sueño se les pasa, o como suele el tiempo a jugadores.

Son hechos los poetas de una masa dulce, suave, correosa y tierna, y amiga del hogar de ajena casa.

El poeta más cuerdo se gobierna por su antojo baldío y regalado, de trazas lleno y de ignorancia eterna.

Absorto en sus quimeras, y admirado de sus mismas acciones, no procura llegar a rico como a honroso estado.

Las páginas finales empalman, por su parte, con la misma benevolencia ecuánime. Lo importante no es la multitud de malos p. 107 .

58 Novelas ejemplares, ed. J. B. Avalle-Arce, Castalia, Madrid, 1982, t. 1, 
poetas, sino la presencia de algunos buenos, que todavía no faltan. Al retornar a su Madrid de siempre se halla muy feliz de saludar y pegar la hebra con viejos y excelentes amigos, que son además tan finos poetas como el joven Luis Vélez de Guevara, "que se puede llamar quitapesares" (II, 168). Claro que se encuentra también con grandes hipócritas y hasta con alguno de los desertores de la batalla parnasiana, pero tiene gran cuidado de guardarse de pendencias e invectivas, no por renunciar a su justo vejamen, sino guardándolo para la ocasión propicia. La academia argamasillesca ha encajado la seria derrota supuesta por su Viaje al Parnaso, pero no dejará de estar ahí siempre, pues de ello se encarga cierto eterno gusto español por los malos poetas, comparados esta vez con hueras calabazas y sus semillas:

Desta dulce semilla referida, España, verdad cierta, tanto abunda, que es por ella estimada y conocida.

Que aunque en armas y en letras es fecunda, más de cuantas provincias tiene el suelo, su gusto en parte en tal semilla abunda.

$(\mathrm{V}, 220-225)$

El lejano Parnaso está ahora semiolvidado y sólo llegan de él nuevos indicios de su incurable locura. Apolo escribe en la Adjun$t a$ acerca de su cabeza más que nunca afligida de "váguidos" bajo el castigo del sol canicular. Expresa también sus temores a un nuevo asedio, por lo cual él y las musas aran de sal los campos para que no se levante otra generación espontánea de la sangre allí vertida por los malos poetas. La batalla contra los traidores a la poesía no tendrá nunca fin, e inevitablemente habrán de sucederse nuevos episodios bélicos. ¿Acaso no ha de lucharlos cada nueva generación? Pero Cervantes, al menos, ha cumplido ya con su turno de servicio y no va a estar allí para verlos.

Duerma, aunque por poco tiempo, en paz la fementida academia de la Argamasilla, pero ¿y la "otra" academia? Cervantes conocía y admiraba las academias de Italia, como ejemplo y modelo de lo que no cabría nunca tener en España. Con elocuencia asimilable a un mudo testimonio, su Viaje del Parnaso no se ocupa para nada de aquéllas ni de cuanto en el terreno del arte significaban. Nótese que el proyecto de viajar al Parnaso equivalía a una ilusión de acogida y reconocimiento por la más absoluta de las academias, la única donde el clasicismo no habría muerto pa- 
ra transformarse en planta de invernadero o programa adoptado en frío por y para profesionales de la literatura. Por supuesto, la ausencia de este otro "legítimo" sector académico es sólo relativa, pues queda valorada por el Viaje del Parnaso a través del tema indirecto de Italia. Es de notar que Apolo pide auxilio a España, con todos sus problemas a cuestas, pero no a Francia ni a Italia, como pone de relieve Mercurio:

De Italia las riberas he barrido;

he visto las de Francia y no tocado, por venir sólo a España dirigido.

$(\mathrm{I}, 329-331)$

La galera de Mercurio va a pasar de largo ante estas dos naciones. Es obvio que ni él ni el Parnaso esperan nada de Italia, caída en un academicismo de eruditos inflexibles y casi igual de infecundos, por otro camino, que los ignorantes argamasillescos. Cuando la nave cruza por delante de Génova, Mercurio ordena dejarla "a la siniestra mano" y seguir su derrota "por la diestra" (III, 134), pues, como todo el mundo sabía, la única distinción de aquella ciudad era su insaciable sed de oro. Tampoco hay ningún intento de hacer la menor escala en "la ancha romana y peligrosa playa" (III, 138), uno de los versos sin duda más sopesados en toda su vida por Cervantes (Roma, tierra de "anchuras" morales y, en años tridentinos, nada favorables a la poesía $)^{59}$. Nápoles, ciudad al fin "española", no es más que escenario de la conspiración de los Argensola para alzarse "con perezosa tiranía" con "la ciencia que a ser divinos guía" (III, 201). A su vuelta del Parnaso, y estamos supuestamente en mayo de 1612, Cervantes renueva allí sus mejores recuerdos juveniles, pero no encuentra ninguna actividad literaria de altura. Se celebran desde luego en Nápoles espléndidas fiestas en honor de los regios matrimonios hispano-franceses, pero son de exclusivo carácter cortesano y caballeresco. Cervantes hasta piensa en escribir una relación de las mismas, proyecto en el que se le anticipa un burócrata de la corte virreinal ${ }^{60}$, tan digno por lo demás de olvido como el

59 La anotación de Rodríguez Marín (Viaje del Parnaso, 225) se muestra aquí ingenuamente atada al positivismo de los tiempos cuando no ve en aquella "peligrosa playa" más que un simple dato geográfico, que ilustra con las prevenciones de un libro moderno sobre navegación del Mediterráneo.

60 Se llamó, según declara allí Cervantes, "el curioso Don Juan de Oquina”' (VIII, 370), tesorero de la corte virreinal. El texto, impreso en Madrid 
mismo ostentoso y estéril festejo. Cervantes debía saber ya que la academia reunida en torno a Lemos (bien llamada de los Ociosos) era un completo fracaso y hasta reverdecía los laureles argamasillescos, en su círculo íntimo, con el lamentable género de las comedias improvisadas o "de repente". Comprometidos todos a la risotada, malgastaba en ellas su talento Mira de Amescua, mientras el gordo sacerdote Bartolomé Leonardo de Argensola hacía las delicias de todos en la interpretación de chuscos papeles femeninos.

En la mejor respuesta que cabía dar a la conducta desleal de Lemos y los Argensola; Cervantes cautela de este modo contra el señuelo de Italia, en el que él mismo había creído también por un momento. Igual lo hacía el Passagero de Cristóbal Suárez de Figueroa, cuando, al dirigirse hacia aquellas tierras, recordaba a sus compañeros de viaje que en ninguna parte se imprimen libros tan a la ligera como en la otra Península ${ }^{61}$. Italia no es solución, lo mismo que tampoco lo es el Parnaso, que no existe y aun si existiera no merecería la pena. El "contraviaje" había tenido como una de sus dianas el desmitificar los falsos paraísos ${ }^{62}$ y Cervantes le suma ahora la devaluación del Parnaso o, en su equivalencia, la de aquel otro edén de la literatura que sus compañeros de generación identificaban a la ligera con una Italia idealizada.

Si España es desesperante, Italia no vale tanto la pena y más que nunca estaremos hoy de acuerdo en el saldo favorable que, frente al sesteo académico de la otra Península, arrojaba el febril hervidero creador en torno a Cervantes. No hay por qué desperdiciar energías en busca de una perfección que no se da en ninguna parte. El poeta a la altura de sus obligaciones no tiene, por tanto, escapatoria a su compromiso con el arte y no puede escatimar su sacrificio ni excusarse con unas condiciones menos que ideales para dar cuanto lleva dentro de sí. Por duro que ello resulte, es en aquel Madrid inhóspito (y en el que después de Cervantes han llorado también tantos poetas) donde hay que levantarse todos los días para la obra que, a modo de un servicio público, se debe crear allí y no en otro lugar. Es preciso hacerlo, además,

en 1612 (licencia de 31 de agosto de aquel año), se considera hoy perdido, pero se conserva un extracto del mismo en Jenaro Alenda y Mira, Relaciones de solemnidades y fiestas públicas de España, Madrid, 1903, p. 163.

${ }^{61}$ El Passagero, p. 149.

62 Chesney, The Countervoyage, p. 58. 
con elegancia y buen ánimo. Lo contrario sería querer irse al Parnaso, o como iba a decir siglos después Aldous Huxley, desertar "to the side of the angels". Lo cual, como se sabe, es para un artista "the most odious of treasons".

No se trata con esto de ninguna consideración anacrónica, pues los frutos por los que se conoce el árbol estaban muy a la vista. Las academias italianas habían desertado en masa al lado de los ángeles, y léase aquí el cómodo espacio de un manierismo paralizador, que aislaba al poeta de la vida real y había metido a las letras de aquella Península por un callejón sin salida. El interés en la literatura italiana parece haberse extinguido para Cervantes con la vida de Torcuato Tasso (1544-1595) ${ }^{63}$, insigne producto de las academias y víctima también de la intolerancia y estrechez doctrinal de las mismas. Cervantes se acerca con gran cautela al neoaristotelismo académico y tridentino, pero con su “ ¡nada de Parnasos!' termina por distanciárselo igual que el opuesto espíritu argamasillesco ${ }^{64}$. El discurso erudito de los innumerables tratadistas consideraba la poesía a modo de un ideal absoluto y codificable, a la vez que como objeto de un culto cuyo pedantesco sacerdocio les estuviera en propiedad reservado. Pero la personificación de la poesía como aquella maravillosa doncella del Parnaso significaba desde un principio la imposibilidad metafísica de su posesión por parte de nadie. Cervantes ha escuchado de sus hermosos labios su deseo de no someterse nunca a manos humanas y permanecer para siempre libre y dueña de sí misma. La poesía es un ideal inalcanzable fuera de su continua búsqueda y ninguna mayor estulticia para un vate tonto ni listo, ni para una insigne academia, que el intentar lo contrario. Por eso Cervantes no hubiera creído hoy tampoco en la poesía pura.

${ }^{63}$ El Viaje del Parnaso menciona dos veces a Tasso (II, 134 y V, 87) bajo igual encarecimiento de antonomasia poética. Para el sentido de la admiración cervantina a Tasso véase Alban K. Forcione, "Cervantes, Tasso, and the "romanzi" polemic", $R L C, 44$ (1970), 433-443. Sobre la presencia de ideas literarias de Tasso en la madurez de Cervantes, Antonio Vilanova, "El peregrino andante en el Persiles de Cervantes", BABL, 22 (1949), 124-129.

${ }^{64}$ No sería tampoco la única vez que Cervantes igualara bajo una misma denuncia de rampante filisteísmo la rusticidad sanchopancesca y la pedantería neoaristotélica: "A glance at Renaissance treatises on poetic theory reveals that the degree of deformation in Cervantes' caricature of the learned poet is not nearly so great as a modern reader would suppose" (ALBAN K. Forcione, "Cervantes and the freedom of the artist", Romanic Review, 61 [1970], p. 253). 
El retorno cervantino del Parnaso cumple así su habitual función autocrítica de la cultura humanística de su tiempo. Su querella más inmediata es el doble falseamiento de la misma, tanto en su volverse moneda de vellón como en su retirada a la trinchera conservadora y autoritaria de las academias. Suponen éstas, aun en el mejor de los casos, un concepto irrealista, por demasiado cómodo, de la poesía y una manipulación interesada de la misma que la somete (para Cervantes muy contra natura) al servicio de las ambiciones y carreras de los poetas: "El elogio y la autocontemplación parecen esconderse en estas pequeñas repúblicas cortesanas que copian la estructura jerárquica del poder y su codificación"'65. En respuesta esencial a la misma clase de problema, el "contraviaje" utilizaba, en cuanto género, su profunda erudición clásica para intimar a fin de cuentas la vanidad de la misma ${ }^{66}$. El Viaje del Parnaso se ríe de dicha cultura si por ella se entendía no un noble espíritu y un verdadero saber sino, como había llegado a ser lo más frecuente en su época, un mero almacén de fórmulas y muletillas poéticas, y de ahí travesuras como su parodia del trilladísimo 67 "Infandum, regina, iubes renovare dolorem"' (Eneida II, 1):

- Mucho, me respondió, mucho te subes en tus preguntas; calla y obedece. sí haré, pues no es infando lo que jubes.

Gristianamente, la poesía requiere de los suyos un amor respetuoso, pero no la adoración reservada a Dios. Enraizado en el Erasmo que invitaba al saboreo de las Sagradas Escrituras y rechazaba a los ciceronianos ${ }^{68}$, Cervantes continúa pensando en la literatura como algo que el hombre hace desde sí mismo para su propio goce y el del prójimo. Goce que es, en sí una experiencia noble y educadora, a la vez que una recompensa muy superior

${ }^{65}$ A. EGIDo, "Una introducción a la poesía y a las academias literarias del siglo XVII", p. 12.

${ }^{66}$ Chesney, The Countervayage, p. 210.

${ }^{67}$ Véanse aquí las correspondientes anotaciones de Rodríguez Marín y Herrero García.

${ }^{68}$ El común rechazo del ideal del poeta doctus por Erasmo y Cervantes es visto en relación con la polémica anticiceroniana del primero por ALBAN K. Forcione, "Cervantes' "La gitanilla" as Erasmian romance", en Cervantes and the Humanist vision: a study of four Exemplary Novels, Princeton University Press, Princeton, 1982, p. 174. 
a todas las riquezas. Llevada al terreno del poeta, la docta ignorantia, en cuanto paradoja angular del humanismo cristiano, significa que aquél habrá de reconciliarse de antemano con ese otro imperfecto costado que, por el hecho de ser hombre, tendrá siempre de "poetastro". Es sólo en el seno de esa modestia (y no en otros superbi colli) donde el poeta se encuentra a sí mismo y a su arte como preparación para las más altas empresas creadoras. Quien no lo entienda así se encontrará sacrificando a dioses falsos y ello ayudará a comprender que la importancia concedida por Cervantes al subdiscurso del poetastro no es fortuita ni meramente pintoresca. En cuanto variante del morio, este "poetón" terminará por asumir una voz sapiencial, en sutil aplicación de ese "ser estulto es ser hombre" 69 que reformula al paulino stulti propter Christum (I Cor. 4.10). Por el lado de la autosuficiencia o soberbia del saber no quedará más alternativa que la de convertirse en ese desdichado y auténtico poetastro que, en su caricatura de la Stultitiae Laus, se despestaña (conforme a un ritual "académico") para conseguir los aplausos de otro "legañoso" como él" ${ }^{70}$. El dios Apolo ha tenido que escuchar en su Parnaso, y de boca de un ridículo poeta indigente, la voz con que la paradoja cristiana proclama como un alto ideal estético el dar "pasatiempo al pecho melancólico y mohino" (IV, 22-23) ${ }^{71}$. Conforme a la dinámica usual de aquella literatura del "loco", ha sido una figura de acento bufonesco la encargada de proclamar las verdades centrales del poema.

Para dentro de casa, la defensa cervantina de una poesía culta y de sanas raíces grecolatinas significa todo lo contrario de un clasicismo a ultranzas académicas, y en realidad constituye también un llamamiento irenista al desarme interior del mundo de las letras patrias. Ese mundo que, al compás de toda la sociedad

${ }^{69}$ Antonio Vilanova, "Erasmo, Sancho Panza y su amigo don Quijote", en Erasmo y Cervantes, Lumen, Barcelona, 1989, p. 107.

${ }^{70}$ Elogio de la locura, trad. A. Rodríguez Bachiller, Aguilar, Madrid, 1967, cap. 50 , p. 217.

${ }^{71}$ Su presencia en Erasmo, básica para la apertura y valoración de éste a la literatura carnavalesca, es estudiada por Joel LeFEBVRE, Les fols et la folie. Étude sur les genres du comique et la création littéraire en Allemagne pendant la Renaissance, Klincsiek, Paris, 1968, p. 227. Me he referido en otra ocasión al papel liberador de Erasmo y su adopción de la literatura del "loco" como génesis de una modernidad literaria: "En rigor, se trataba del ideal de la relaxatio animorum que define el De sermone de Pontano, antes de la escisión del humanismo en el siglo xVI y de su cautividad por el aristotelismo académico y contrarreformista" ("La locura emblemática en la Segunda parte del Quijote", p. 106). 
española, se viene cerrando entre infinitas pendencias al saludable espíritu crítico de que el Viaje del Parnaso da discreto ejemplo. Gran lección para aquella otra stultifera navis que era la aturdida corte madrileña, capaz de acuñación tan única como mentidero ${ }^{72}$ y que, haciendo del embuste una forma de vida, en lugar de academias tiene sólo gallineros. Pero este otro ideal cervantinamente "académico" no podía abrigar en el día la menor esperanza realista, y nadie lo sabía mejor que el poeta morosophos ${ }^{73}$ retornado del Parnaso.

Entre el crimen argamasillesco de profanar la poesía y la idolatría de la misma conforme al academicismo italiano, queda amplio espacio para el juego creador encaminado a disipar melancolías conforme a la estética erasmiana del "mostrar con propiedad un desatino" (IV, 27) 74 . Cervantes no tiene, a la hora del gran adiós, ningún otro secreto trascendental que comunicar a sus mejores amigos y lectores. Se halla satisfecho de sí mismo y de su obra (en cierto modo hasta de su propia vida) y quiere que todos lo sepan. Por supuesto que no le va a enmendar la plana a Aristóteles ni a tanto docto tratadista, pero sí puede hablar con autoridad acerca de cómo ha de ser vivida la literatura. "Poetastro" y todo, entiende de estas cosas, al cabo de sus años, mucho más que el jovenzuelo Apolo en aquellas alturas parnasianas, tan vueltas de espaldas a la realidad. El sentido final de su Viaje del Parnaso no es así sino de un claro orden ético. Es por esto por lo que ha recurrido al terceto, propio de la poesía más reflexiva, frente a la octava rima que venía prefiriendo la literatura académica sobre estos temas. Su iconología de la poesía viva en el Parnaso introduce una sutil novedad, pues, cuando Don Quijote (II, 16) hacía hincapié en pintarla como auxiliada por todos los saberes, conforme a un concepto muy neoaristotélico, la hermosísima ninfa, aunque "toca y apunta de cualquiera ciencia"' (IV, 185), no comparte allí su morada sino con "la divina y moral filosofía":

Moran con ella en una misma estancia la divina y moral filosofía,

72 "Ciervantes y el mentidero de San Felipe" (Viaje del Parnaso, ed. RoDRÍGUEZ MARÍN, apéndice 1).

73 MAURICE LeVER, Le sceptre et la marotte. Histoire des fous de cour, Fayard, Paris, 1983, "Le morosophe ou fol sage", pp. 191-214.

${ }^{74}$ Forcione, "Madness and mystery: The exemplarity of Cervantes' Novelas ejemplares", en Cervantes and the Humanist vision, p. 28. " "Desatinos de propósito": The ugly shapes of satire", en Cervantes and the mistery of lawlessness, "Introducción". 
el estilo más puro y la elegancia.

$$
\text { (IV, 190-192) }
$$

Cervantes se reconsagra al concepto de raíces platónicas nunca de él abandonado, del poeta como depositario de responsabilidades de orden moral y colectivo ${ }^{75}$ de que en todo momento ha de hallarse dispuesto a rendir cuenta. Es lo que vuelve también tan grave (por vía recíproca) que una sociedad que se cree omnipotente deje de aquel modo morir de hambre a sus poetas. Al menos por su lectura del Pinciano (1596) habría de conocer la idea horaciana de que uno de los oficios del poeta consiste en el noble cometido de "fundar repúblicas" "76. No es, pues, ninguna casualidad que donde hay malos poetas haya también mal gobierno y viceversa. Por eso veía Cervantes como el peor de los síntomas que las academias se enquistaran en el casticismo manchego o bien que, en la cara opuesta de la misma dinámica, los poetas se sintieran tentados a fugarse a Italia o, lo que era aún peor, a cierta clase de Parnasos.

Francisco Márquez Villanueva Harvard University

${ }^{75}$ La continua preocupación moral del poema es resaltada por GeOFFreY STAGG, "Propaganda and poetics on Parnassus: Cervantes' Viaje del Parnaso", Cervantes, 7 (1988), 23-38.

${ }^{76}$ Alonso López Pinciano, Philosophia antigua poética, ed. A. Carballo Picazo, CSIC, Madrid, 1953, t. 1, epístola III, p. 214. La relación entre ambos autores ha sido estudiada en especial por Jean F. CANAVAGgro, "Alonso López Pinciano y la estética literaria de Cervantes en el Quijote”, Acerv, 7 (1958), 13-107. 